\title{
Grundtvigs økonomiske tænkning
}

\author{
Af Vagn Wahlin
}

$\emptyset k o n o m i t c e n k n i n g e n$ som adskilt område er utilladeligt, men nødvendigt.

Som i så meget andet af Grundtvigs tankeverden er der vedrørende synspunkter på økonomien tale om dels, at han lærer af fortidens tænkning og samtidens virke, dels at han samtænker økonomien $\mathrm{i}$ vekselvirkning med andre sider af sit samfundssyn, sin menneskeforståelse og sin opfattelse af forholdet mellem mennesket og Gud.

Dette er for mig et grundvilkår ved al beskæftigelse med Grundtvigs tænkning og virke. Vi begår derfor bevidst og systematisk vold mod den organiske fremvækst af hans opfattelser ved at pille et enkelt element - i.e. $\emptyset$ konomi-forståelsen - ud af helheden og underkaste dette element en nøjere analyse. På den anden side er netop sådanne udskillelser af enkeltdele til nøjere analyse en forskningsmoessig nødvendighed af arbejdsmæssige og intellektuelle grunde.

Man vil derfor - og delvis med rette - kunne bebrejde mig, at jeg ved at rive synspunkter ud af deres sammenhæng har begået vold imod deres egentlige mening hos Grundtvig.

Et andet vigtigt problem ligger i selve sprogbrugen. I de sidste ca 200 år - dvs. fra økonomien udskiltes som en egen videnskab har man udviklet et fagsprog og en anvendelse af formallogiske metodikker og argumentationsformer udtrykt $\mathrm{fx}$ i matematificeringen af den økonomiske videnskab, som var Grundtvig så grundlæggende imod:

"Turde jeg derfor sætte Matematikken i Kirkens Band" (med maskinerne og den økonomiske 'Vindskibelighed', gjorde Grundtvig gerne dette; men)...."selv Matematikken, i sig selv den dødeste og tommeste af alle vore Kundskaber" 
(bliver dog nyttiggjort $\mathrm{i}$ den moderne naturvidenskab og $\mathrm{i}$ teknologien) ${ }^{1}$

Fagsprogets fremmedgørende effekt gjorde Grundtvig i digt og prosa oprør imod og benyttede $\mathrm{i}$ stedet bevidst dansk talesprog uddybet med sproglige og poetiske billeder. Derfor må forskeren delvis begå vold imod Grundtvigs tekst for at få hans tankeverden ført over i en nutidig forståelig polit-økonomisk ramme og sprogføring - med de muligheder for tolkningsfejl heraf følger. Omvendt vil det ikke være muligt konsekvent at benytte moderne polit- $\emptyset$ konomiske termer i analysen, da disse igen hænger sammen med strukturerende tankesystemer, der giver netop kun deres præcise mening til de enkelte termer ved den indre meningshelhed i systemet. Altså, med fare for at sætte mig mellem to stole og ikke blive forstået af hverken indforståede grundtvigianere eller systemorienterede $\emptyset$ konomer må jeg fors $\emptyset \mathrm{ge}$ mig med et kompromis, udtrykt så rimeligt og så bredt forståeligt som muligt i nutidens skriftsprog.

Et tredje problem ved at udtrække Grundtvigs økonomiske tænkning af det mægtige og komplekse livsværk ligger $i$, at Grundtvig sjældent ulejligede sig med at fortælle sine læsere om, fra hvilken faglig eller politisk litteratur, han havde sine opfattelser. De var jo netop igennem brugen i den bestemte situation og i den udgivne tekst blevet Grundtvigs - han var arkitekten og andres tankeelementer var blot mursten $\mathrm{i}$ tankens bygningsværk. ${ }^{2}$

Enhver, der har sat sig lidt ind i fx Saint-Simons arbejder fra 1820'erne om Det industrielle System (1821-23) eller Den nye Kristendom (1825) kan genfinde lignende synspunkter hos Grundtvig omkring arbejdets grundlæggende betydning for velstanden, om middelstandens antifeudale frihedskrav - der ikke har betydning for arbejderne - og om næstekærligheden som den afgørende sociale drivkraft i modsætning til de klassiske engelske økonomers organiserede egennytte, osv. Men har Grundtvig sådanne inspirationer til en samfundsforståelse på første hånd eller anden hånd eller blot som almene brudstykker fra tidens debat? Det er med hans bevidste samfundspåvirkende sigte vanskeligt at sige. Samtidig hermed skrev og talte han ud fra og ind i samtidens almindelige forståelse af polit-økonomiske forhold. Her kan der på det øko- 
nomiske felt ses påvirkninger fra ældre opfattelser og fra samtidige franske og engelske økonomisk-teoretiske skrifter samt fra nogle tyske - ligesom visse engelske og franske opfattelser måske er transporteret ind $\mathrm{i}$ den danske debat via tyske oversættelser eller tyske tidsskriftartikler. I det hele er Grundtvigs omfattende avis- og tidsskriftlæsning vigtig for at forstå hans inspirationskilder.

Et fjerde problem ligger i spørgsmålet: Hvilken Grundtvig? Grundtvig før englandsopholdet? Grundtvig som samfundsdebattør 1830-48? Grundtvig som politiker 1848-55? Grundtvig sugede hele livet til sig og transformerede tidens åndelige strømme til indlæg i forskellige sammenhænge til forskellige tider - og hvilken tid og situation er så den rigtige Grundtvig? Og hvilke skrifter dertil er så de rigtige. Skal vi lægge vægt på det, han trykte, $\mathrm{fx} i$ Danskeren, inden sine store Rigsdagstaler eller på det, som han efter Rigsdagstidendes referat faktisk sagde, bl.a. under indtryk af de andre debattørers indlæg.

Det for analysen nødvendige udvalg er derfor både for indskrænket og antagelig også skævt. Men jeg har gjort mit bedste. I praksis danner Mands Minde forelæsningerne (1838 - 39), Danskeren 1848f og Rigsdagstidende grundstammen i mit materiale, mens andre skrifter er mindre benyttet.

Den sammenhaengende økonomiske opfattelse, han udtrykker 1848 i Danskeren - som er aftrykt efter hovedteksten sidst i denne artikel - demonstrerer, at han havde en økonomisk helhedsopfattelse og ville drage de politiske konsekvenser deraf. Dette $g ø r$ det forsvarligt bredt ud i forfatterskabet at søge efter enkeltelementer af økonomiske udsagn - som de optræder mange steder, når man først har fået øjnene op derfor - til supplement, nuancering og uddybning af den økonomiske helhedsopfattelse, han senest 1848 var nået frem til. Vi kan tillade os at gå i de pædagogiske skrifter, i salmer, prædikener, digte og sange og udtolke over i økonomiens forstandssprog Grundtvigs økonomiske tænkning, som den foreligger andre steder i folkelig, kristelig eller poetisk sproglig klædebon, fordi han selv har givet os i politisk nøgtern sprogform sin økonomiske tænknings hovedstruktur. 
De aldre фkonomiske opfattelser til o. 1800

I lærebøger om den økonomiske tænknings udvikling går det som i lærebøger om teologiens udvikling: en hovedstrømning bryder frem, bliver væsentlig eller måske herskende og klinger så ud, ofte i et bittert opgør med en efterfølgende hovedstrømning. I den samfundsmæssige virkelighed er forholdet normalt anderledes, jvf. skematisk fremstilling deraf i Fig. 1.

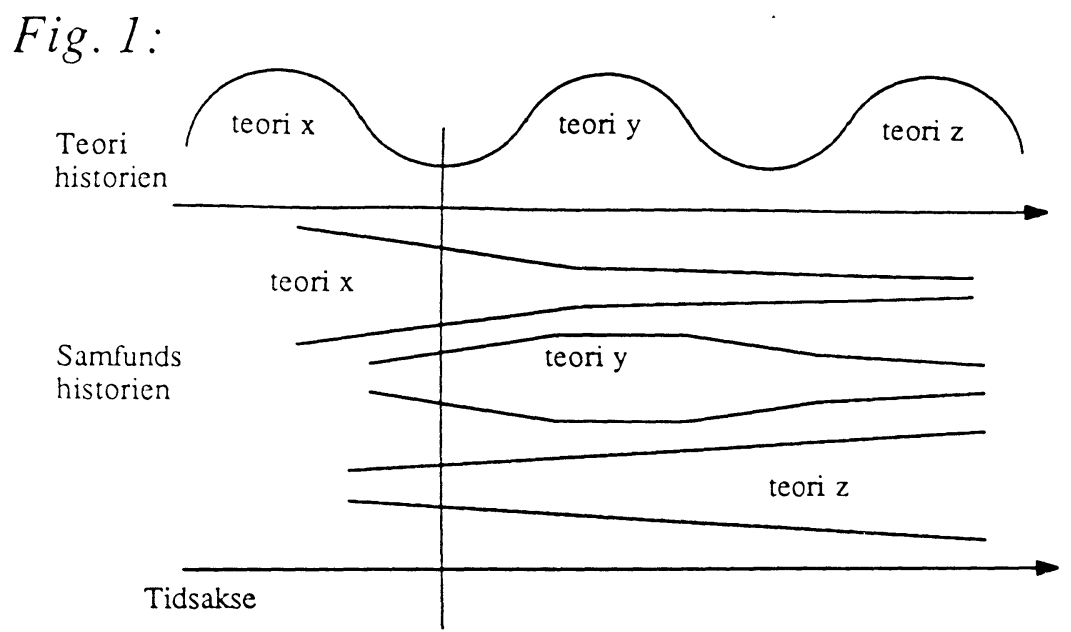

Snit fx. o. 1830

Efter teorihistoriens metodik vil økonomisk teori "y" have afløst " $\mathrm{x}$ " ved tidsnit 1830. Efter samfundshistorien vil folk uddannet under teori " $\mathrm{x}$ " stædigt sidde $\mathrm{i}$ betydningsfulde poster, mens teori "y" dominerer på universitet og $\mathrm{i}$ debatten, og " $\mathrm{z}$ " vil være på vej. En vekselvirkning mellem forskellige teoretiske økonomiopfattelser vil i den sociale praksis være det centrale, en vekselvirkning, der rækker bagud i tid og udad over miljøets og landets grænser.

Derfor er vi nødt til at skitsere, hvad af 18. århundredes polit$\emptyset$ konomiske tankegods og praksis Grundtvig - så snart han åbnede øjne og ører som samfundsindivid efter Steffens' foredrag (dvs. o. 1803) - nødvendigvis måtte have for øje og tage stilling til, mere ellẹr mindre bevidst derom. Dernæst må vi skitsere træk af samtidens debat og virkelighed, som synes at have påvirket Grundtvig. 
En egentlig økonomisk debat både om generelle opfattelser og praktiske tiltag i Danmark får et afgørende skub fremad 175657 , hvor regeringen opmuntrer til en sådan og derefter med dannelsen af Det kgl. Danske Landhusholdningsselskab 1769 sætter en ramme herfor, og bl.a. økonomiske tidsskrifter tillades.

I anden halvdel af 1700-tallet kan i den danske polit- $\varnothing$ konomiske litteratur genkendes følgende 3 hovedretninger, som også afspejles i sider af den praktiske politik, selvom de ikke i samtiden benævntes sådan: Merkantilisme, fysiokratisme og kameralisme mens elementer af det, som blev til økonomisk liberalisme, var på vej.

Merkanitilismens to ældre hovedretninger aftegner sig: "bullionismen", der koncentrerer opmærksomheden om mængden af ædelmetal som baggrund for et lands evne til at virke frit over for andre nationer og "handels- og produktionsmonopolismen", der søgte at sikre det indenlandske erhvervsliv på bekostning af import og derfor bl.a. var fortaler for en høj beskyttelsestold. Betalingsbalancen skulle være positiv for ikke at bringe landet $i$ $\emptyset$ konomisk afhængighed af andre lande. Skønt der er tilløb til en ekspansionistiske tænkning i den senere del af perioden, er dog merkantilisternes hovedopfattelsen længe, at ressourcerne generelt er begrænsede, så at et lands berigelse - ved krig eller handel sker på bekostning af andres velstand. Hovedvægten i den $\emptyset$ konomiske forståelse ligger på cirkulationssfæren og sekundær produktionen. Klassemæssigt var merkantilismen en teori for cirkulationssfæren, dvs. for købmænd, der også var producenter i fabrik og manufakturer. Inden for cirkulationssfæren var det især den monetære politik, som fremmer af økonomisk vækst, der optog senmerkantilisterne, og hvor især seddelmængdens størrelse og sikkerhedsrelation til henholdsvis jord og ædelmetal stod i centrum.

Fysiokratismen fra Frankrig opererede fra o. 1750 med primærproduktionen - og særligt landbruget - som det afgørende for et samfunds velstand og magt. Arbejdskraften på landet (og dermed også soldater-udskrivningen) skulle øges væsentligt. Byerne stod ikke i centrum og cirkulationssfæren var nødvendig for fordelingen af goderne, men var ikke i sig selv værdiskabende. Det var klassemæssigt en politik for godsejere og frie mellemlags-bønder. Staten skulle regulere mindst muligt og overlade mest muligt til 
egennytten, så ville økonomien blomstre. Det gjaldt altså om at slække på love og gamle systemer, der hindrede effektivitet $\mathrm{i}$ agrarsektoren, at fremme den interne cirkulation (nedbryde indre toldskranker) og at bruge agrar-teknologi som drivkraft i en velstandsstigning. Det var en dynamisk tænkning, hvor "mad nok" ville dæmpe sociale spændinger.

Kameralismen udvikledes særligt i de tyske indlandsstater. Udgangspunktet var en stærk statsmagt, som via skatter, offentligt forbrug og statslig direkte engagement i økonomien afbalancerede de forskellige $\varnothing$ konomiske kræfter i samfundet og derigennem sikrede det fælles bedste for alle statens indbyggere. Det er en tænkning efter bureaukraternes hoved og må ses i samspil med, at disse udviklede klassemæssige træk på tværs af de gamle feudale bånd. Der er tale om en dynamisk økonomisk tænkning, der blot ikke gik ud fra, at en hidtil ureguleret økonomi af sig selv ville udvikle sig hen mod en mere organiseret vækstøkonomi. Sociale spændinger erkendtes og modvirkedes af staten. ${ }^{3}$

Byggende på ældre kollektive forståelser inden for købstæderne $\mathrm{i}$ lavene og i agrarsektoren i landsbysystemet opereredes der med en opfattelse af cyklisk reproduktion - dels inden for årets gang, dels inden for menneske-livet og slægternes gang: barn, tjenestekarl, bonde, aftægtsmand eller: barn, lærling, svend, mester, aftægt. Der var tale om opfattelser i folkets bredere lag, hvorimod det var fælles for bonden, mesteren og herremanden at handle ud fra en patriarkalsk ansvarsfølelse over for deres undergivne. Forpligtelserne var gensidige, men forskellige. Forpligtelserne var for de undergivne opad: lydighed, trofasthed og arbejde ; og de var for de magtfulde nedad i relation til de undergivne: beskyttelse, forsorg og sikring af livsfornødenheder og produktionsmidler.

Cyklisk reproduktion opererede med en opfattelse af, at man sparede og sultede sig ud af dårlige år og åd sig ud af gode - med lidt til kistebunden, lidt til skat og afgift og lidt til medgift. Bondehandel og marked kunne give noget ekstra, men var ikke grundlaget for livsfornødenhederne. ${ }^{4}$ Dette billede passer $\mathrm{fx}$ ikke i Vestjylland, hvor netop handel i gårdmandssønnernes unge år var baggrund for velstand og ægteskab, jf. Blichers, En karlighedshistorie. Alligevel var der ikke tale om en generel dynamisk økono- 
misk tænkning, men om en blanding af gammel kollektiv opfattelse og en individuel fremdrift via handel.

Moralsk фkonomi har baggrund i den cykliske reproduktionstænkning og moralsk-etiske begreber fra lutherdom og de reformerte om arbejdsmoral, om næstekærlighed og om pligten til ærligt arbejde, og der opereres med et begreb om en rimelig belønning for et hæderligt stykke arbejde. Selvom godsejeren har magten til at skrue fæstebondens afgift i vejret, må han efter bondesamfundets normer ikke gøre dette, men skal holde sig til det sædvanlige. Det er ikke udbytning i sig selv, som bestrides, men aendringer heri udover den lokale opfattelse af ret og rimelighed, dvs. moralen. I købstaden fastsætter lavet prisen ikke efter markedets muligheder for afsætning, men efter at sikre mestre og svende en rimelig belønning for deres møje. Nabo-hjælp og noget til landsbyens fattige opfattedes ikke som en del af noget særligt $\emptyset$ konomisk, men var netop grundet i lokal solidaritet og medmenneskelig hensyntagen til egne og lokalsamfundets behov, dvs var moralsk. 5

Traditionel-historisk og naturbestemt økonomi var opfattelser, som $i$ vekslende styrke fandtes $i$ alle de forudgående opfattelser og tilsagde bevidst eller underforstået, at økonomiske ændringer måtte tage højde for (eller søges undgået) af historisk-traditionelle grunde, eller fordi de naturgivne betingelser satte bestemte grænser. Disse historisk (tidsmæssige) og geografisk-naturbestemte grænser stod i modsætning til en opfattelse af, at der fandtes eller kunne findes almengyldige eller evige фkonomiske opfattelser.

Evigt gyldige фkonomiske love kunne bl.a. udledes af Bibelen. "I dit ansigts sved skal du æede dit brød" m.v. Arbejdet er en pligt, et guddommeligt og evigt pålæg og vilkår for mennesket. Næstekærligheden er et evigt bud også i økonomien. Mennesket har pligt til at mangfoldiggøre sig og til at sørge for sig og sine - men altså også for sin næste. Mennesket har pligt til at udnytte sine evner, jf. lignelsen om, at forvalte sit pund ret og få det til at mangfoldiggøre sig. Over for disse og flere religiøst begrundede $\emptyset$ konomiske mønstre stillede såvel oplysningstidens filosoffer som senere liberale og socialistiske økonomiske tænkere andre "evige" grundbegreber. Adam Smith $\mathrm{fx}$ opererede med en "naturgiven" menneskelig egennytte som en urkraft $\mathrm{i}$ de menneskelige rela- 
tioner - han fordømte den ikke, men mente, at selviskheden under de rette betingelser kunne bringes til at virke for et fælles bedste.

Til stor forundring for lærde økonomer og til ærgrelse for betrængte skatteministre viser det sig, at dele af den moralske фkonomi lever i bedste velgående i 1990'ernes Danmark. Af dem, som ikke kan kontrollere den moralske økonomi, eller - som fx embedsmænd i centraladministrationen - ikke kan nyde godt af den, gives den nutidige moralske økonomi naturligvis alskens nedsættende navne, som sort фkonomi osv. At det er de herskendes $\varnothing$ konomiske teorier og opfattelser af $\varnothing$ konomi og moral, det er galt med, og ikke befolkningens opførsel, er endnu ikke i 1990 sivet ind de rette steder.

Dette var blot et eksempel på, at dele eller hele sektioner af ældre politisk- $\varnothing$ konomiske opfattelser kan leve videre i praksis længe efter, at de af teoretikere og administratorer anses for udslukte og døde. Således også for Grundtvig på hans tid. Man behøver ikke at være konservativ eller forblindet for at have øje og øre og hjertelag for at forstå den faktiske sociale relevans af økonomisk tænkning og handling, som på bjerget erklæres for irrelevant gammeldags eller rent ud fejlagtigt forstået.

Ovenfor er blot nogle karakteristika $\mathrm{i}$ grove linjer ridset op vedrørende nogle af de vigtigste af de økonomiopfattelser, der indgik i det arsenal af økonomisk forståelse, som med rødder bagud i tiden stod til rådighed for den interesserede. Særligt i de sidste årtier af 1700-tallet forefindes flere konkurrerende teorier og de spredtes hurtigt internationalt gennem bøger og tidsskrifter. De monetære teorier sættes i samspil med beskæftigelsen (statens pligt til at skaffe arbejde) og almindelig økonomisk vækst til gavn for alle. Den faktiske økonomiske politik i Danmark afspejlede tilpasning til hjemlige traditionelle og naturgivne forhold af et bevidst udvalg af tidens teorier, $\mathrm{fx}$ omkring landbolovene (der er fysiokratisk inspireret) fra $1788 \mathrm{ff}$ og statens indgreb (kameralistisk og merkantilistisk inspireret) på mange felter. ${ }^{6}$

Udenlandske strømninger $i$ фkonomitankningen ca 1800-1850

Skønt der naturligvis var fortalere for og protester imod Adam Smith', The Wealth of Nations (1776-77), så er næppe noget andet 
polit-økonomisk værk blevet udbredt så hurtigt eller har haft en sådan gennemslagskraft.

Dette hang sammen med, at navnlig i England havde samfundsforholdene ændret sig så meget, at ældre økonomiske opfattelser ikke længere kunne bruges til at forstå, hvad der reelt foregik. Uden en polit-økonomisk samfundsforståelse, der kan danne en fælles forståelsesramme for handlinger $i$ de besluttende samfundslag, går det politiske system og administrationen $\mathrm{i}$ baglås. Derfor er der et samspil mellem samfundsforandring og politøkonomiske teorier, men normalt således, at teorierne i de mere udviklede lande kommer bag efter samfundsændringerne. I mindre eller anderledes udviklede lande kan teorierne fors $\varnothing$ ges overført af et styre eller en elite, uden at de samfundsmæssige forhold modsvarer teorien - ofte med forfærdende menneskelige omkostninger til følge, hvilket bl.a. efterkrigstidens ulandspolitik giver alt for mange eksempler på.

Adam Smith gjorde op med en række indbyggede og artikulerede opfattelser i de tidligere økonomiske teorier.

Statens rolle skulle mindskes fra igangsætter og fordeler til en "natvægter-stat", hvor det centrale lå $\mathrm{i}$, at staten sikrede, at de givne friheder for de økonomiske kræfter ikke blev misbrugt til at skabe nye begrænsninger og nye monopoler. Markedet, hvor udbud og efterspørgsel mødtes uden begrænsninger, kom i centrum, således at producentens prisforlangende og forbrugerens behov mødtes og afbalanceredes $\mathrm{i}$ den rette pris. De modsat rettede interesser fandt af sig selv - som hjulpet af en "usynlig hånd" - frem til den i forhold til helheden rette pris for varen.

Statens vigtigste positive bidrag lå dels $\mathrm{i}$ at sikre et stabilt og effektivt pengesystem, dels $\mathrm{i}$ at regulere, hvor der på grund af knaphed på ressourcer kunne opstå monopol-situationer, $\mathrm{fx}$ at sikre fri skibsfart, hvor der af naturgivne årsager kun kunne være én havn, osv.

I arbejdet lå kilden til samfundets velstand, og ved at lade enhver arbejde så frit som muligt ud fra egne interesser ville den menneskelige trang til arbejde og vinding af sig selv føre til forøget produktion fremmet af arbejdsdeling og formidlet til den rette pris gennem markedet og distribueret gennem fri næring $i$ transport og handelssektoren. 
Det er centralt i relation til Grundtvig, at Adam Smith fremhæver arbejdsdelingen som baggrunden for en stærkt stigende mængde af arbejde grundet på $\mathbf{3}$ faktorer:

1. den enkelte arbejders dygtighed stiger

2. spildtiden mellem forskellige arbejdsfunktioner nedsættes i forhold til, hvis den enkelte arbejder udfører alle trin i processen

3. maskiner kan forøge den enkelte arbejders indsats til at dække fleres arbejdsindsats.

Menneskenes medfødte evner er mindre forskellige end ofte antaget, siger Adam Smith. Det centrale i forskellen mellem en filosof og en arbejder ligger i skik og brug og uddannelse, begges funktion er samfundsmæssigt nødvendig. ${ }^{7}$ Væesentligt er det, at i industrien opnås, efter Adam Smith, den maximale arbejdsdeling og mest effektive udnyttelse af tid, råstoffer og maskineri hvorfor det også er dér, den største værditilvækst skabes.

Ønsket om frihandelen med især korn var imidlertid ikke hos Adam Smith et nyt element. Det var internationalt stærkt hævdet bl.a. af fysiokratismens store tænker Francois Quesnay: Maximes générales, maxmime XXV, i Le droit naturelle $(1765 \text {, s } 956 \mathrm{f})^{8}$

Adam Smith påviser arbejdsdelingens omkostning for arbejderen som menneske ved arbejdets reduktion til "a few simple operations", og arbejderen:

- ...."has no occasion to exert his understanding". Arbejderen får ingen åndelig træning "and generally becomes as stupid and ignorant as it is possible for a human creature to become... But in every improved and civilized society this is the state into which the labouring poor, that is, the great body of the people, must necessarily fall, unless government takes some pains to prevent it"

Lov og orden, frihed og stramme finanser var mottoet for en god stat efter Smith' lære..$^{10}$

Malthus' lære om forholdet mellem stigning i fødevareproduktionen lineart og stigning i befolkning eksponentielt fastslog, at fattigdomsproblemet ikke kunne løses ved fattiglove, som via 
overførselsindkomster ikke gennemtvinger begrænsninger i befolkningens vækstrate. Hvis der ikke fandtes muligheder for stadige teknologiske forbedringer, ville lønningerne tenderer til at ligge på reproduktiongrænsen, hvor den nødvendige arbejdskraft lige netop kunne opretholdes. David Ricardo viser først selv hen til teknologiske fremskridt (Principles, chap. VI, s. 120) som en løsning på problemet - men i 3. udgave af Principles (1821) har han tilføjet et nyt kapitel, hvor han betvivler, at nettofaktorindkomst og jordrente plus profit følges ad. Heraf følger en mulighed for, at der bliver relativt mindre til opsparing (investering) og beskatning, og derfor efter en tid mindre til løn trods øget mekanisering. Dvs at mekanisering og fabriksdrift ifølge Ricardos senere opfatttelse alligevel ikke kunne løse fattigdomsproblemet (dette må Grundtvig også have ment, selvom det ikke siges direkte).

I den klassiske liberal-økonomiske skole betød pengemængden i sig selv mindre, da kun den relative værdi af varer herved blev fastlagt.

Utilitaristerne med Jeremy Bentham, James Mill, John Stuart Mill, m.fl. samledes i 1820'erne og 1830'erne omkring liberale tidsskrifter som Edinbourgh Review og Westminister Review og udbredte deres skrifter i store oplag. Deres opfattelser er bl.a. præget af David Hume og udmøntes i mottoet om "den størst mulige nytte for de flest mulige mennesker". Som Adam Smith's usynlige hånd $\mathrm{i} \emptyset$ konomien, der forvandler de manges selvinteresse til helhedens bedste, således så Hume og efter ham Bentham og utilitaristerne, at menneskets virksomme egennytte ikke altid var skadelig for samfundet eller skete på bekostning af andre. Men staten og moralen til sammen måtte skabe reguleringsmekanismer, så den enes velfærd ikke blev opnået på bekostning af andre. Forældre hjalp, hvis de kunne, deres børn uden ydre tvang og gavnede derved sig selv (fik et kærlighedsbehov opfyldt), de hjalp børnene til at klare sig i verden og frembragte derved individer, der var nyttige for helheden, for samfundet. ${ }^{11}$

Robert Owen gør op med troen på, at den frit svævende egennytte kan føre til noget samfundsmæssigt godt og fremhæver for såvel personer som stater en bevidst indsats for: 
"the combination of extensive mental and manual powers in the individuals of the working classes; to a complete identity of private and public interests, and to the training of nations to comprehend that their powers and happiness cannot attain their full and natural development but through an equal increase of the power and happiness of all other states $^{n}$ -

her går skillelinien mellem det, som er og det, som bør komme. ${ }^{12}$

John Stuart Mill går ved sammenfatninger af sine tidligere fors $\emptyset \mathrm{g}$ i "Principles of Political Economy" (1848) ind for ejendomsrettens ukrænkelighed vedrørende det, som er menneskeskabt - men "any such sacredness does not belong in the same degree to landed property. No man made the land. It is the original inheritance of the whole species." Mill finder, at der er sket positive forandringer i Frankrig 1848, hvor regeringen for første gang ikke så på arbejderne som blot "instruments of production, worked for the benefit of the possessors of capital". Problemet ved socialisterne er, at de ikke har forstået konkurrencen og dens konstruktive sociale funktion, men reelt har forvekslet konkurrencen med monopolet og ikke har forstået "that monopoly in all its forms, is the taxation of the industrious for the support of indolence, if not of plunder. ${ }^{13}$

I Frankrig rejste der sig en bred og kritisk debat om Smith, Malthus og Ricardo. Ricardo besøgte 1822 en af hovedkritikerne Sismonde de Sismondi (1773 - 1842) i Geneve. Ricardo beretter herfra, at Sismondi var seriøs i sin kritik og havde hele menneskehedens velfærd for $\varnothing j e:$

"He holds that the great cause of the misery of the bulk of the people in all countries is the unequal distribution of property, which tends to brutalize and degrade the lower classes. The way to elevate man, to prevent him from making inconsiderate marriage is to give him property, and an interest in the general welfare; - thus far we should pretty well agree, but when he contends that the abundance of production caused by machinery, and by other means is the cause of the unequal distribution of property, and that 
the end he has in view cannot be accomplished while this abundant production continues..."

så fejler Sismondi efter Ricardos opfattelse vedrørende både forudsætninger og følger. ${ }^{14}$ Hvad vi skulle udlede mange steder af Sismondis skrifter siges kort her af Ricardo. Virkningerne af maskineriets uendelige produktionsstrøm og den menneskelige degradering samt den ulige fordeling af ejendom må ses og politisk behandles i sammenhaeng mellem det politiske system og staten. Befolkningsvæksten må stoppes af en fornuftig ægteskabspolitik, og det arbejdende folk (som via arbejdet skaber velstanden) må gøres til borgere med en klar interesse $\mathrm{i}$ at opretholde og sikre samfund og stat. Det sker efter Sismondi ikke ved at lade kapitalens og maskin-teknologiens uligheder køre ud i sin logiske konsekvens (som Ricardos økonomiske tænkning kunne føre til). Derimod skabes opbakning om samfund og stat ved at give mennesket noget at miste økonomisk og politisk. Hvor mennesket ikke går aktivt med både privat - over for familierne og samfundsmæssigt, som borger, for at opretholde den generelle velfærd og samfundsorden, dér bliver den lille selvstændige næringsdrivende den første taber. Sismondi ser derfor med bekymring, at de mindre selvstændige håndværkere og mellemlagsbønderne på familiebrugene i praksis var ved at blive proletariserede. De ville blive udslettet, hvis ikke der politisk blev skabt rammer for at sikre netop dem som bærende elementer i samfundet. $^{15}$

En række af disse tanker med kritik af Manchester-liberalismen genfindes også i den engelske debat fra 1820'erne og fremefter bl.a. hos utilitaristerne og bl.a. fremført i Westminister Review og Edinbourgh Review - tidsskrifter, som med numre tilbage til 1820 fandtes i Grundtvigs bibliotek ifølge optegnelsen ved hans død over hans bøger.

Tilsvarende kan man finde nøgtern kritik - grundet på anderledes forhold i Danmark - af liberalismen i danske økonomiske tidsskrifter fra 1820 'erne og 30 'erne, ${ }^{16}$ - men med klar tilslutning til hovedtankerne om $\mathrm{fx}$ næringsfrihed og frihandel.

Også Saint-Simon $(1760$ - 1825) må igen med ind i billedet som inspirator for den europæiske debat om økonomien som videnskab og praksis i første del af 19. århundrede. Det er en 
debat, som Grundtvig $m a ̊$ have suget til sig af, skønt det ofte kan være vanskeligt at påpege konkret, hvor og hvordan Grundtvig har tilegnet sig tidens idémæsssige hovedstrømninger.

Som Grundtvig selv var Saint-Simon primært en seer og inspirator, hvis mange og spændende ideer andre måtte tage sig af at få nyttiggjort og udbredt ${ }^{17}$ - bl.a. af August Comte, der redigerede og delvis selv skrev 3. del af "Catéchisme des industriels" under titlen: Système de politique positive.

Saint-Simon ser som de fleste i samtiden arbejdet som samfundets egentlige kilde til velstand. Arbejdsdelingen og især de nye manufakturer og industrier har skabt en ny klassedeling mellem arbejder og kapitalist, der afløser de ældre stænders modsætninger i samfundet. Arbejdernes eneste aktiv er salget af deres arbejdskraft. De har ingen primær-interesse i den nye middelklasses (kapitalisternes) anti-feudale frihedsidéer, som i sidste ende kun vil tjene den nye middelklasse af kapitalister og statstjenere med en stadigt hårdere udbytning af arbejderne til følge. Saint-Simon opererer med en "bastard-klasse" af advokater m.fl., der havde tjent overgangen fra feudalstyre til borgerligt styre, men søgte at vinde egne positioner uden at producere noget kontant. Præst og adel havde reelle funktioner $\mathrm{i}$ det gamle samfund, og det har industrialister og videnskabsmænd i det nye. Arbejdernes interesser ligger $\mathrm{i}$ en omformning af samfundet og en omfordeling af produktionsmidler og produktionens resultater, som kan sikre værdiskaberne en rimelig levevis. ${ }^{18}$ Hvis ikke det skal ende $\mathrm{i}$ stadigt hårdere sociale kampe, må sådanne omfordelinger til. Ejendomsretten skulle bestå, men eventuelt fordeles anderledes og bredere, og også virksomhedslederne - som de bedst egnede til at forestå produktionen - skulle have deres plads. Men den sociale nød skulle afhjælpes gennem medmenneskelig moral ved naestekarlighed i praksis på kristent grundlag.

Også i Tyskland vandt de engelsk-franske polit-økonomiske teorier frem, men fik snart en særlig national drejning, hvis nationalpolitiske konsekvenser bl.a. sås i etableringen af Toldforeningen 1834. ${ }^{19}$ Grundtvig var - som alle i København før 1842/43 - som en naturlig del af sin løbende orientering vel hjemme i tysk debat bl.a. via tidsskrifter m.v. Når jeg alligevel vover at lade tyskernes kombinering af kameralisme og liberalisme med preussisk stats-raison ligge som en væsentlig påvirkningskilde, skyldes 
det Grundtvigs egen afstandstagen fra tysk teoretiseren og hans klare henvisninger til engelsk-vesteuropæisk polit-økonomisk tænkning.

Forholdet mellem фkonomi og politik og mellem teori og praksis

Den "rene" økonomi, som vi - velvidende, at det delvis er en karikatur - kan finde i visse lærebøger fra slutningen af 19. århundrede og til i dag eksisterede ikke for tænkerne 1750 - 1850. Den økonomiske tænkning selvstændiggjordes klart netop i dette århundrede og abstraheredes af analytiske grunde $\mathrm{i}$ principielle kategorier, der lod sig behandle i strukturelt og matematisk formsprog - $\mathrm{fx}$ tydeligt udviklet hos David Ricardo. Alligevel viser en gennemgang af blot titlerne på alle de ovenanførte værker, at udgangspunktet for dem var samspillet mellem økonomi og politik i samfundet. Forfatterne vil ikke blot beskrive og analysere de faktisk forekommende økonomiske forhold, men vil konkret anvise veje til at aendre eller påvirke den økonomiske side af den samfundsmæssige udvikling - dvs deres formål er nyttiggørelse af deres overvejelser i praktisk politik. Derfor kan man ikke uden vold på den fortidige virkelighed adskille økonomi og politik i videnskabsudviklingen. Men det er som oven anført alligevel nødvendigt af analytiske årsager.

Det centrale er, at Grundtvig altså var på linie med både det bedste $\mathrm{i}$ den for ham forrige generation af økonomiske tænkere og med de mest indflydelsesrige af sin samtids økonomiske teoretikere, når han ikke adskilte mellem økonomi og politik i sine analyser og ej heller adskilte mellem sit virke som tænker og som politiker.

Den polit-økonomiske tænkning skulle bygge på erfaringen og dens betydning vises i konkret praksis.

Om det første skriver John Stuart Mill vedrørende "praktikere" kontra "teoretikere":

"But, although both classes of inquirers do nothing but theorize, and both of them consult no other guide than experience, there is this difference between them, and a most important difference it is: that those who are called 
practical men require specific experience, and argue wholly upwards from particular facts to general conclusion; while those who are called theorists aim at embracing a wider field of experience, and, having argued upwards from particular facts to a general principle including a much wider range than that of the question under discussion, they argue downwards from that general principle to a variety of specific conclusions. ${ }^{20}$

Sismondi og de engelske klassiske økonomier såvel som utilitaristerne byggede alle på omfattende erfaringer og iagttagelser, de selv havde gjort, og inddrog andres $\mathrm{i}$ deres undersøgelser og konklusioner.

Igen og igen fastslår Grundtvig, at historien (som er folkenes erfaring) og den enkeltes erfaring er det, man vedrørende praktisk politik skal bygge på og ikke "Hjærnespind af fin Ætherluft" - sagt med brod til de national-liberale $1849 .^{21}$

\section{Klasser og фkonomiske forhold i Danmark i det 19. århundrede}

For at forstå den danske økonomiske og sociale virkelighed, som Grundtvig iagttog og virkede $\mathrm{i}$, er det nødvendigt som bidrag til en rammeforståelse at opridse visse historiske og samfundsmæssige hovedtræk, der må antages at have været vigtige for hans forståelse af de historiske og samfundsmæssige sammenhænge. Det vil sige, at jeg her med friske streger tegner en historisk skitse, ikke som Grundtvigs samtid eller den senere nationale historieskrivning så virkeligheden, men som vi i dag kan se den, og som jeg selv med bred baggrund $i$ forskningen har fremlagt den i en række større artikler (Wåhlin, 1980a og b, 1982, 1986a og b, 1987, 1988a og b).

Efter et lavpunkt i 1600-tallet ses i hele Nordvest-Europa og Danmark en klimatisk langtidsforbedring, der bliver tydelig i 1700tallet og forsætter til vore dage. Somrene er blevet lidt varmere, men især mindre regnfulde $\mathrm{i}$ de afgørende måneder for høstresultatet.

Som en anden generel tendens over hele Europa ses gennem 1700-tallet og stærkt stigende i 1800-tallet en almindelig befolk- 
ningstilvakst. Alle lokale forskelligheder til trods er det generelle billede ud over Europa som i Danmark, at væksten mere skyldes et fald $i$ dødeligheden - især blandt småbørn - end et stigende antal børnefødsler.

Parallelt med de klimatisk forbedrede muligheder for fødevareproduktion og befolkningsvæksten fremkommer gennem 1700tallet i flere lande og herunder Danmark:

1. en statslig organiseret interesse $\mathrm{i}$ et forbedret jordbrug,

2. en videnskabeliggørelse af jorbrugsdrift og agrar redskabsteknologi,

3. en forøget intern og international debat og informationsstrøm gennem agrarøkonomiske tidsskrifter, bøger og Landhusholdningsselskaber, -

4. store og stærkt stigende andele af den primære agrarproduktion blev markedsorienteret - i Danmark således op mod $25 \%$ af en almindelig bondegårds produktion år 1800.

Om forholdet mellem faktorerne og hvilken faktor, der nu var mest betydningsfuld, er der ført lange videnskabelige diskussioner. Det centrale for mig at se er, at et sæt af samvirkende indre og ydre faktorer og tendenser medvirkede til at skabe forudsætningerne for og påvirke det konkrete gennemslag af grundlæggende ændringer i agrarsektoren. Det er rimeligt at tale om ikke én, men en række parallelle eller forskudte og dog forbundne agrarrevolutioner i Nordvesteuropa sidst i 1700-tallet og først i 1800-tallet.

Statsmaessigt tabtes i løbet af det 19. århundrede først Norge (1814) og senere Slesvig-Holsten (1864), hvorved det danske rige (bortset fra de i samtiden økonomisk og politisk mindre betydningsfulde bilande som Island, Grønland, Færøerne, Guinea, Vestindien, osv) endelig blev en ren national stat, Danmark.

Politisk- фkonomisk havde den oplyste enevælde ved et samarbejde mellem fremsynede inden for godsejerne, topembedsmændene og storborgerskabet gennemført en række grundlæggende $\emptyset$ konomiske og kulturelle reformer, som fremmede en glidende og relativt smertefri overgang til et moderne borgerligt samfund. Reformsystemet lagde fra $1788 \mathrm{f}$ ud med ophævelse af gårdmands- 
hoveriet (arbejdsrenten), afløsning af naturalieafgifter (naturalierenten) og med at fremme bøndernes $\mathrm{k} \emptyset \mathrm{b}$ af deres gårde til fri ejendom (feudal pengerente afløst af moderne obligationsrente). Dernæst blev bondegårdene (familiebrugene) udskilt i selvstændige bedriftenheder fra det gamle kollektive driftssystem i landsbyen. Arbejdskraft til både gårdmænd og godsejere sikredes ved, at husmandsbrugene ved udskiftningen tildeltes så lidt og så ringe jord, at husmanden og landarbejderen ikke kunne ernære sig og sin familie ved arbejde på egen jordlod, men nødvendigvis måtte sælge egen og ofte familiens arbejdskraft til gårdmænd og godsejere. Eller også måtte husmanden lære et håndvaerk og gennem arbejdsdeling og specialisering forøge værdien af sit arbejde og sin produktion. Det heraf følgende klassemæssigt synliggjorte fattigdomsproblem ordnedes ved nye sogne- og skattebaserede ordninger af fattigfors $\emptyset$ rgelsen $1803 \mathrm{ff}$. Almueskolevaesenet ordnedes 1814 på sognebasis. Endelig ophævedes de fleste produktions- og handelsmonopoler (bortset fra Færøerne, Grønland og delvis Island, samt kornsalget til Norge) og et ændret toldsystem gennemførte på mange områder en friere handel fra 1799.

Denne affeudalisering og borgerliggørelse markeredes politisk og forfatningsmæssigt af årstallene 1834 med repræsentationsret i stænderforsamlingerne, 1849 med de borgerlige frihedsrettigheder og grundlov for at slutte 1915 med den almene valgret også for kvinder. Men i virkeligheden må det ses som en ét-hundredårig proces begyndende med det første kommunale selvstyre vedrørende fattigvæsen (1803), skoleforhold (1814) og det fulde kommunale selvstyre (1837-1841), afsluttende med fagbevægelsens samfundsmæssige anerkendelse (1899) og de store erhvervsorganisationers inkorporering i statssystemet under og efter Første verdenskrig.

$\varnothing$ konomisk blev landet for alvor inddraget i verdensøkonomien, og kapitalismen slog afgørende igennem inden midten af 1800tallet; men som en agrar-kapitalisme af en helt anden natur end den engelske industri-kapitalisme. En egentlig internationalt præget kapitalisme er først slået afgørende igennem i Danmark siden 1960 og da tydeligt ikke med vægten lagt på de klassiske industrigrene, men på et varieret og fleksibelt system af mindre og mellemstore virksomheder og træk $\mathrm{i}$ retning af et postindustrielt informationssamfund. 
Urbaniseringen slog afgørende igennem som bredt samfundsmæssigt ændrende tendens i den sidste fjerdedel af 1800tallet, men med en specifik og hurtigt omstillelig og smidig struktur i mindre industri- og erhvervsvirksomheder. Kulturelt, klassemæssigt, økonomisk og politisk fastholdtes de afgørende skel mellem urbansektoren og agrarsektoren. Men i Danmark var agrarsektoren den dynamiske og dominerende del af samfundet $i$ modsætning til andre vesteuropæiske kapitalistiske lande. Derfor har jeg valgt begrebet agrarkapitalisme som betegnelse for hele samfundsformationen i 19. århundrede.

I Danmark - som i Vesteuropa - kan der med arbejdsdelingens fremtrængen, naturvidenskabens sejrsgang og hele moderniseringsprocessen af samfundet iagttages en opløsning af det gamle stændersamfunds sammenbindende kræfter og dermed en tendens til samfundsmæssig adsplittelse og selvstændiggørelse af de 3 hovedsektorer: andslivet (ideologien), de medmenneskelige forhold (sociale relationer, familie og landsbyfællesskab) og фkonomien. Dette kan illustreres således: (Fig. 2).

Det vil sige, at statens (og kommunens) vækst og magt kan ses om en følge af, men også i vekselvirkning med, væksten i de adsplittende sociale kræfter. Men vækst - også i bureaukratisk magt - har en tendens til at blive et formål i sig selv, og præcis vedrørende dette balancepunkt er det, at den liberale kritik af "staten" med rette sætter ind i 19. århundrede.

Bevidshedsmaessigt og kulturelt ændredes - set i den store målestok - forholdene også glidende i løbet af 19.århundrede. Enevældens mere formelle "vanekristendom" eller fornuftprægede religionsforkyndelse gennem statskirken blev angrebet $\mathrm{i}$ det vasentlige indefra. Rammen blev efter 1849 en rummelig Folkekirke, som formåede $\mathrm{i}$ hovedsagen at fastholde århundredets to centrale retninger, grundtvigianismen og Indre Mission. Trods store kulturpolitiske slagsmål og en meget aktiv friskolebevægelse uden for den offentlige barneskole valgte dog kun få procent af de grundtvigsk bevidste gårdmænd og folk fra det bedre borger 


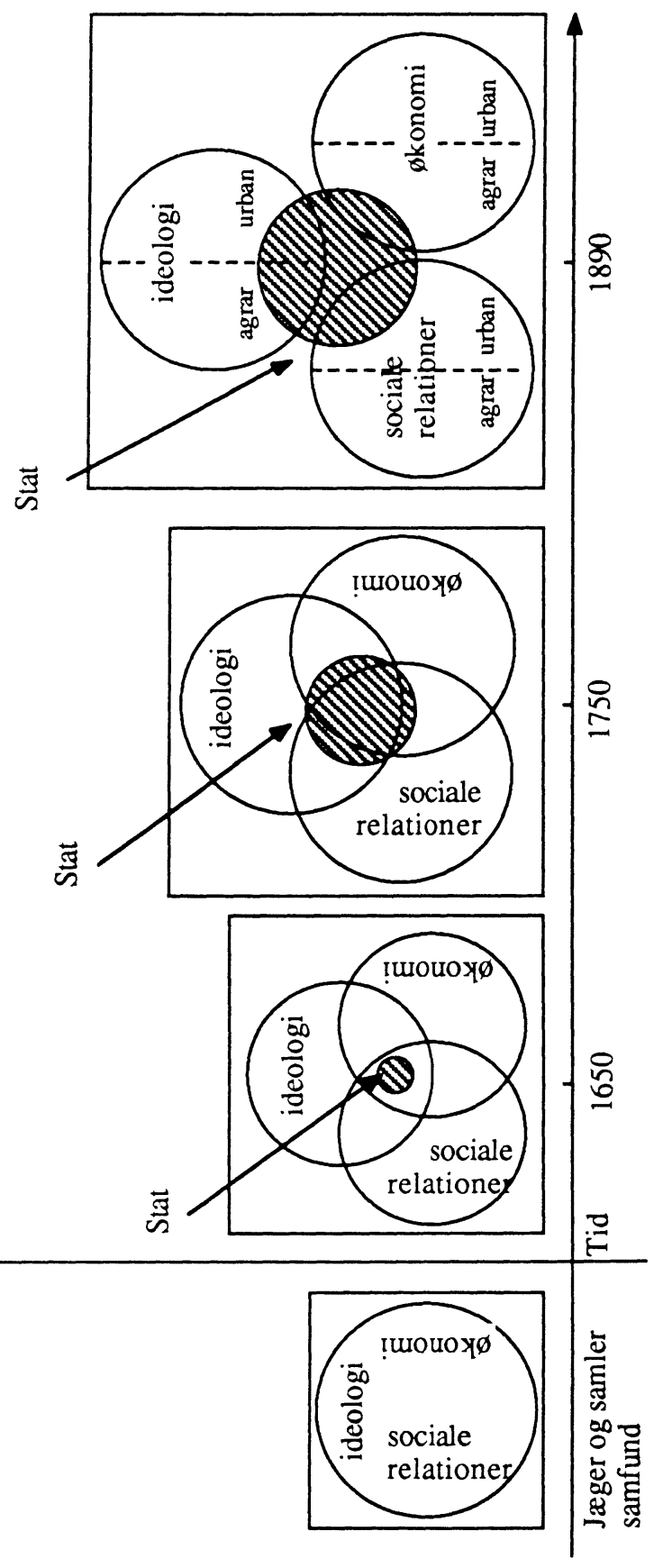




\section{Kommentar til figur 2:}

Firkanten repræsenterer samfundstotaliteten på alle planer og livsområder.

Cirklerne: ideologi, ikke- $\emptyset$ konomiske sociale relationer og $\phi k o n o m i$ (produktions-sfæren) repræsenterer de 3 centrale samfundsmæssige sfaerer, hvori menneskelig aktivitet, intermenneskelige forhold og menneskelige forestillinger foregår $\mathrm{i}$ et stadigt vekselspil, men også med stigende autonomi (for de forskellige sfærer).

Skraverede midter-cirkler repræsenterer staten og den voksende sociale aktivitet til at sammenknytte de stadigt mere autonome sfærer, dvs. politikken.

Cirkel-i-firkant til venstre repræsenterer det totale sammenfald af $\emptyset$ konomi, ideologi og sociale relationer før agrarrevolutionens bonde- $\phi k o n o m i e r$ opstod.

En opføring af modellen til nutiden ville vise den tiltagende opsplittelse, men tillige statens, det offentliges og politikkens vækst - eksplosivt - for at modvirke de ud fra et totalitetssynspunkt uheldige følger af opsplitningen.

skab i købstæderne, at sætte deres børn i privatskole. Den afgørende kulturelle og bevidsthedsdannende indsats i agrarsektoren foregik fra 1860'erne for de voksne omkring folkehøjskolerne, forsamlingshusene, missionshusene og gennem aviserne m.v.

Det urbane verden - med København som centrum - udvikledes økonomisk og socialt på en anden måde end agrarsektoren, men også i vekselspil med hovedtendenserne i den internationale $\emptyset$ konomi. Kombinationen af dels Københavns handels-kapitalistiske knæk ved handelsflådens tab og byens almene nedtur efter Napoleonskrigene, dels agrarsektorens relative styrkelse efter landboreformerne medførte, at der op til midten af 1800-tallet ikke fandtes en aggressiv urbankapitalisme, der over for statsmagten kunne tvinge ændringer i samfundsudviklingen igennem efter sine interesser. Trods tilbageslaget ca 1815-30 også i agrarsektoren medførte dette $\mathrm{i}$ forhold til i fx England en relativ styrkelse af den strukturelt og klassemæssigt moderniserede agrarsektor. 
I Danmark manglede natur-ressourcerne kul og jern, hvorfor en urban-industriel udvikling som i England, Nord-Frankrig, Belgien og Ruhr-egnene i Tyskland ikke var økonomisk relevant i første halvdel af 19. århundrede.

Den forøgede kvalitet og produktivitet opnået gennem arbejdsdeling kunne derfor til efter midten af 1800-tallet foregå i helt små (enkeltmands) eller mellemstore bedriftenheder på sjældent over 20 medarbejdere. En "storborger" i Danmark o. 1840 var altså noget helt andet og langt mere beskedent end, fx en storborger i England eller Paris. Relativt var afstanden derimod stor i København mellem storborgeren, småborgeren og arbejderen. Mens gårdmændene ved landboreformerne var rimeligt sikret som agrarsamfundets bærende klasse i og med, at gårdmændene sad på 75\% af den dyrkede jord, så var der ikke samme moderniserede underbygning af de urbane småborgeres position trods deres store bidrag til den samlede urbane produktion. Tværtimod var deres organisationer $i$ lav og korporationer under stadigt angreb fra liberal side for at få gennemført den almene næringsfrihed, som ville true sikkerheden i småborgernes sociale status og moralsk-korporativt fastsatte priser. 1857 indførtes den borgerlige næringsfrihed.

Herved er skitseret nogle hovedtræk i et kapitalistisk domineret dobbelt- $\phi$ konomisk system i Danmark, hvor agrarsektoren og bysektoren har hver sin særegne og selvstændige økonomiske udvikling samtidigt med, at der foregår et stadigt vekselspil mellem de to systemer - det er som to nærstående træer, der suger næring af samme jordbund, og hvis grene filtres stadigt tæuttere ind $\mathrm{i}$ hverandre, jo højere man kommer op i kronen, og dog stadigt er to træer. I samklang med de to $\emptyset$ konomier udvikledes også et dobbelt klassesystem med storborgerskab, småborgerskab og lønarbejdere både $\mathrm{i}$ agrarsektoren og $\mathrm{i}$ bysektoren inden industrialismens gennemslag i 1890 'erne, men hvor de to lønarbejderklasser og de to småborgerskaber ikke havde dominerende fælles interesser, som kunne udjævne de systemskabte modsætinger og den socio-økonomiske spænding mellem land og by. I hosstående Fig. 3 er opfattelsen aftegnet. 
Fig. 3:

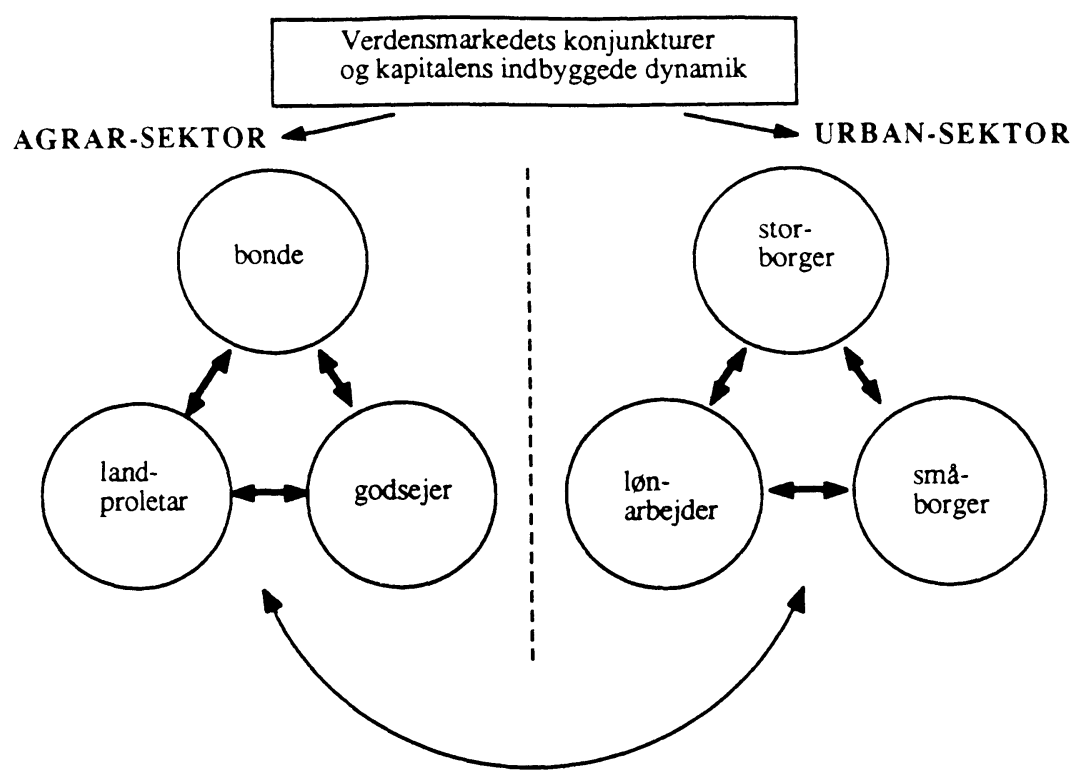

Mellem småborgerskab og storborgerskab i byen, og på landet mellem bønder og godsejere, kan man konstatere en løbende forståelse omkring arbejdslønspørgsmål og retten til at udnytte de lønnedes arbejdskraft mest profitabelt og klassemæssigt vendt imod på landet landarbejderne og i byerne lønarbejderproletariatet. Ligeledes kan man se formaliseret interessefællesskab i form af klassealliancer mellem bønder og landarbejdere og byernes småborgere og lønarbejderproletariatet omkring udvidelsen af og sikringen af de borgerlige rettigheder som stemmeret og lighed for loven m.v. Empirisk kan der derimod ikke konstateres signifikante alliancer mellem godsejere og landarbejdere vendt imod bønderne eller mellem byernes storborgere og lønarbejderproletariatet vendt imod småborgerne. Ad denne indirekte vej kan det ved at se på de alliancer, som ikke kunne realiseres, udledes, at også i Danmark gik i det lange løb den afgørende skillelinie mellem lønarbej- 
de og kapital, mellem proletariat og kapitalister, - selvom størrelsen og slagkraften af bønder og småborgere skjulte dette forhold for den direkte iagttagelse helt op til midten af det 20. århundrede. Men i tiden før Grundtvigs økonomiske tænknings afklaring ca. 1820 - 1840 og næsten 100 år længere kunne det se ud, som konflikten kapital-arbejde kunne undgås eller $\mathrm{i}$ det mindste gives et mere medmenneskeligt acceptabelt forløb end i fx England.

Klassemæssigt blev Danmark særligt i agrarsektoren, men også i urbansektoren, et samfund, hvor middelstand og mellemklasserne - især gårdmændene - fik en helt afgørende betydning og formåede at hævde denne på de fleste af samfundslivets områder.

Det var hverken kapitalister og storborgere, eller arbejdere og proletariat og ej heller kampen imellem dem, som ud fra en helhedsbetragtning dominerede det samfundsmæssige forløb i Danmark i det 19. århundrede. Med agrarsektorens stærke stilling i det råstoffattige land kom bønderne, gårdmændene, der sad på 75\% af den dyrkede jord, til at få en helt afgørende betydning op til omkring 1960. By og land måtte stadigt rette sig til efter hinandens krav, og de organiserede arbejdere såvel som den organiserede kapital kunne ikke styre udviklingen åbenlyst i modstrid med de brede mellemlags interesser.

Politisk, økonomisk, klassemæssigt og åndeligt gav dette baggrund for et $\mathrm{i}$ vesteuropæisk forstand, ja selv i verdenshistorisk perspektiv, enestående pluralistisk og samtidigt homogent samfund gennem det 19. og første halvdel af det 20 . århundrede.

Det var denne økonomisk-sociale virkelighed Grundtvig og hans samtidige levede $\mathrm{i}$ og havde for øjnene - men som krævede en økonomisk og klassemæssig realistisk forståelse for at kunne omsættes i anvendelige og slagkraftige politiske former.

Byborgerskabet og de national-liberale tilbad i poesien den landlige natur - jf. rent fysisk de mange landsteder - og foragtede i hovedsagen gårdmanden som medborger og kunne som oftest ikke acceptere bonden som ligeberettiget samfundsmedlem. Den gamle overklasse af godsejere og adelige foragtede længe både bonde og borger.

Hverken godsejere eller bønder og ej heller storborgere og småborgere regnede socialt set husmænd og landarbejdere og byarbejdere for socialt ligeværdige personer - selvom gårdmændene med rester af den gamle landsbysolidaritet direkte og person- 
ligt, menneske til menneske, kunne yde nabohjælp til sognets fattige uden om fattigkassen, og godsejere og storborgere kunne udvise en endog ret stor patriarkalsk og kristeligt begrundet godgørenhed. 
I relationen menneske-Gud så Grundtvig den foranstående Fig. 2 - hvor firkanten er den historisk-konkrete samfundshelhed således (Fig. 4):

Gud vekselvirker med såvel helheder som enkelt-dele, og enkelt-mennesket vekselvirker med andre mennesker på en række planer og med kollektive enheder på andre planer.

Således er Gud for Grundtvig med på alle planer og i alle mellem-menneskelige forhold - også i økonomien.

$$
\text { Fig. 4: }
$$

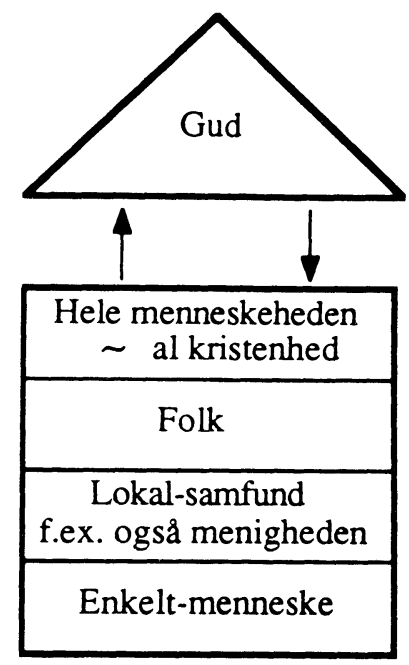

Kommentar til figuren:

I nogle tilfælde taler Gud direkte til det enkelte menneske og mennesket til Gud, fx i bønnen.

I andre tilfælde indgår mennesket i det lokale kollektiv, $\mathrm{fx}$ hos menigheden under gudstjenesten i salmen og omfattes derigennem af det guddommelige.

I atter andre tilfælde er det hele folket - den historisk-nationalt-åndelige helhed - der bliver aktøren for Guds vilje og omvendt folkets fælles redskab, sproget, bliver det medium, hvorigennem mennesket når og nås af det guddommelige.

Menneskelivet i al dets mangfoldighed udspiller sig i forskellige fremtrædelsesesformer på alle 4 niveauer - og disse omfattes igen af hele menneskeheden "al kristenhed". Men vejen til "al kristenhed" går gennem "folket" og dvs gennem sproget (derfor må $\mathrm{x}$ "al kristenhedens" salmer oversættes til dansk og synges på dansk). 


\section{$\emptyset$ konomiske grundbegreber hos Grundtvig}

Grundtvig opererer ikke med en atomistisk samling af enkeltindivider. I stedet ser han en række kvalitativt forskellig, men vekselvirkende sfærer for mellemmenneskelige påvirkningsforhold og livsudfoldelse der billedligt kan forstås som koncentriske cirkler (Fig. 5)

Fig. 5 :

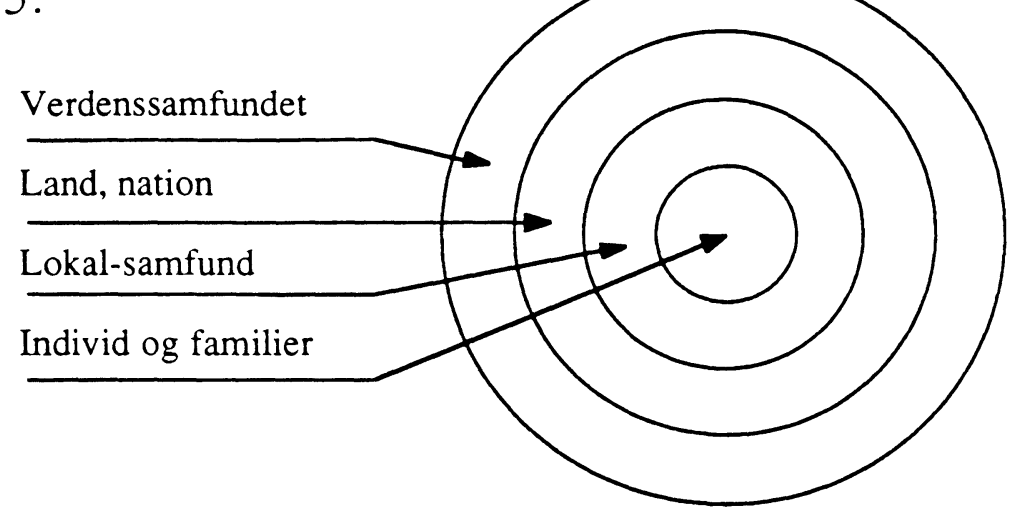

I religiøst-kirkelige sammenhænge er det menigheden (= lokalsamfundet) som sammen med enkeltmennesket og familien udgør kærnen i systemet med national-kirken som borgerlig indretning og hele kristenheden som yderste menneskelige referenceramme.

I politiske-folkelige sammenhænge er det person-familie, dernæst lokalsamfundet og til slut fædrene-landet (=nationen), som er de mest relevante etiketter på cirklerne, mens det abstrakte væsen "staten" nærmest opfattes negativt af Grundtvig undtagen, hvor dette falder sammen med kongen.

I фkonomien er det først det helt nære: husbond, hushold og familie, - dernæst det nære og overskuelige samfund, med $\mathrm{fx}$ umiddelbar udveksling af varer og tjenesteydelser ( $\mathrm{fx}$ i landsbyen eller i en købstad), - noget svagere står i menneskets økonomiske relationer nationen og det regionale marked, - og verdenssamfundet er langt væk, og befinder sig i den yderste cirkel.

Det centrale er menneskelivet: at mennesker fødes, har barndom, ungdom, manddom, alderdom og dør i en stadig kæde gennem tiderne ${ }^{22}$ og må have visse materielle grundvilkår som føde, hus og klæder opfyldt gennem produktion og vareudveksling 
og visse immaterielle eller kulturelle og følelsesmæssige fornødenheder opfyldt gennem troslivet, i kærligheden mellem mennesker, gennem sprog og kultur samt gennem kunst og vid-skab, som Grundtvig kaldte det.

Grundtvigs tænkning om virkelighedens samfund er, at livet er organisk og dynamisk, hvor selve livets vilkår - modsat dødens er $k a m p$, dvs stadige brydninger mellem forskellige interesser og forskellige meninger. ${ }^{23}$

Arbejdet med "Mund og Haand" dvs. såvel åndeligt og intellektuelt arbejde som manuelt-fysisk arbejde var grundlaget for selve eksistensen og for velfærden for den enkelte og for samfundslivet:

(Grundtvig vil have med i Grundloven omkring næringsfrihed det) "som hører til Menneskets utabelige Ret, at han kan have Tilladelse til at ernære sig med sine egne Hæn$\operatorname{der}^{\text {224 }}$

(Fra Mands Minde forelæsningerne, 1838, udkast til 7. forelæsning, titel og tekst:)

\section{Haand og Mund}

...(Jeg maa) prise dem lykkelige, der enten har Munden til Tjeneste eller gode Hænder paa Skæftet, da det aabenbart kun er med Haand og Mund man kan tjene Føden og udrette betydeligt i denne Verden,.."(Grundtvig fortsætter med at diskutere staten og naturlovene, i.e. de efter naturens art nødvendige samfundslove, dvs. sociale grundbetingelser, som ikke kan fjernes af staten, men vel fremmes eller hæmmes i deres udfoldelse)..."naar Forfatningen er de gode Munde og de dygtige Hænder gunstig; thi, som sagt, kun ved dem kan alt menneskeligt naturligt bestaa og $i$ Længden forsvares ${ }^{\text {25 }}$ (Grundtvig fortsætter med betragtninger over historisk beskrevne klasseformer, jf. nedenfor)

(Fra Mands Minde forelæsning, 6. juli)

..."Menneske-Naturens Love ligesaa lidt som andre Naturlove lader sig forandre eller ustraffet trodse.." ${ }^{\text {26 }}$ 
Til sådanne sociale love "Menneske Naturens Love" regnes også af Grundtvig, at mennesker ikke er lige og ej heller socialt kan blive det

.."Den demokratiske Lighed, Franskmændene i Revolutionen efterstræbte, anser jeg for Blændeværk" - men ikke blot er det så, .."at den Højeste dømmer os alle uden Persons Anseelse; der er ogsaa en Ligelighed efter Menneske-Naturens Love, som Historien maa tage i Betragtning" (13.7.1838, Mands Minde)

Grundtvig er altså enig med oplysningstidens økonomer - og med sin samtids engelske og franske økonomer - i, at der er $\emptyset$ konomisk-sociale "naturlove", som det er nødvendigt at forstå for at kunne beslutte historisk konkret om de borgerlige love, der kan forandres.

Grundtvig opererer således med, at der bag ved de historisk og politisk bestemte samfundsinstitutioner og rammer (love) gør sig nogle mere fundamentale, sociale lovmæssigheder gældende - af art og styrke som naturlovene - der ikke kan bestemmes af eller tilsidesættes af magthaverne. Til sådanne økonomisk-sociale grundlove hører altså arbejdets nфdvendighed, som skaber af de samfundsmæssige værdier, og selve livets eksistensvilkår. $\mathrm{Og}$ arbejdet leveres af arbejdskraften i to former, en konkret materiel/fysisk og en mere immateriel, åndelig. Der antages altså de facto en principiel arbejdsdeling i samfundsøkonomien - samt i $\emptyset$ vrigt en arbejdsdeling i hjemmet mellem kvindens og mandens roller.

Heri er Grundtvig altså enig med både fysiokraterne og kameralisterne, de klassiske liberale engelske økonomer og de franske økonomer.

Ligesom arbejdets nødvendighed var et socialt grundvilkår, således anså Grundtvig dets modsætning - dovenskab, løsagtighed, tagen sig selv til rette, tyveri - som en anden social "naturlov". Disse negative tendenser ville dominere, hvis ikke arbejde og ejendomsret blev respekteret og som grundvilkår for et ordnet samfund af alle kræfter blev beskyttet.

Omkring den generelle fattighjælp, som han er så stærkt imod, anfører Grundtvig at "man f $\varnothing$ der Dovenskaben saa Flittigheden maa 
sulte" derved. Omkring spørgsmålet om frie næringsveje mener Grundtvig, at en beskyttelse af de næringsdrivende "kun føder Dovenskab og alt Ondt". Vedrørende forsøgene på i Frankrig og især i Paris på at iværksætte en produktion i de såkaldte "nationalværksteder" med lige løn og udbyttedeling, mener han, at det nok kunne gå, hvis alle var hæderlige, men:

"...da vi er alle Syndere, maa det naturligviis blive splittergalt, naar vi alle behandles som Dydsmønstre, og det af Folk, der selv er Syndere og tit nogle af de Groveste..."

det må gå galt og ende med at gør alle, både rige og fattige, ulykkelige. $^{27}$

Der spores hos Grundtvig ikke nogen tiltro til "naturlig" arbejdsomhed og flid m.v., men klart det modsatte: uden stopmekanismer vil det negative få overtaget.

\section{Klassedeling og фkonomi}

Med ejendomsretten som omdrejningspunkt har alle de anførte $\emptyset$ konomiske retninger konstateret en klassedeling af samfundet, samt at der er sket en fundamental ændring i klassestrukturen. Grundtvig er flere steder inde på, at ikke alle kan være lige $\mathrm{i}$ faktiske sociale vilkår, og at dette ej heller var ønskeligt - kun over for "naturloven" (også de sociale) og Gud er vi alle lige.

Men man kan strabe imod et samfund, hvor "Faa har for meget og Færre for lidt" som han allerede skrev 1820 ved Prams afrejse i "Langt højere Bjerge...", og som han til slut gentager i sin фkonomiske programerklaering i Danskeren, juni 1848.

Den samfundsmæssige ulighed for mennesker er altså et grundvilkår. Udover den socialt-naturskabte ulighed i forhold til den fuldt ud anerkendte samfundsborger, som findes i forhold til børn og oldinge, kvinder, syge og nødlidende uden egen skyld, konstaterer Grundtvig en historisk-klassemæssig ulighed. Som historiker flere steder bl.a. i Verdenshistorien og Mands Minde beskriver han det ældre privilegiesamfund og den samhørende klassedeling. Men skarpest står det generaliseret i Mands Minde 1838 og Danskeren 1849. (Arbejdet er baggrunden for velstand, og 
samfundsindretningen må tage højde herfor for ikke at føre til fejludviklinger som fortidens privilegiesamfund):

.."Man forudsatte nemlig i Middelalderen, at Præsterne altid maatte have de bedste Munde (i.e. solidt åndsarbejde, V.W.), og Adelsmændene de dygtigste Hænder, fordi det en Stund syntes at slaa til. Men man forvexlede dog i Grunden en god Mund med en stor Mund, og dygtige med haarde Hænder,...(og i de katolske lande gik det rent galt); "thi Adel og Gejstlighed beholdt deres Privilegier"..(men staten havde fået ny-opståede behov, hvorpå løsninger måtte findes)..."som den da søgte hos Jurister og staaende Hære, men dels blev Udgifterne derved dobbelte, og dels gjorde disse Munde og Hænder til Fals i Folkets $\varnothing_{\text {jne aabenbart }}$ langt mere Skade end Gavn."

Grundtvig konstaterer videre, at i de protestantisk lande indskrænkedes vel privilegiesystemet, men de stående hære var alle vegne et problem som "en falsk Højre-Haand", og juristerne brugte deres kundskaber både godt og slet.

Men vore moderne sprogbrug kunne vi sige, at ét sæt udbytterklasser havde afløst et andet. At dette ikke er en gal læsning af Grundtvig, ses af, at han umiddelbart efter går over til igen at fremhæve det produktive arbejde fra "dygtige Hænder" og tillige anfører, at alle håndværker og alle flittige bønder burde gøres frie, så at de "har altid noget af deres eget at forsvare baade mod udvortes Fjender og indvortes Ranere", hvorved også den stående hær kunne undværes.

Grundtvig mener dernæst, at præsterne skulle fratages deres embedsmonopol og skolelærerne deres lavstvang, så at staten kun beholdt den "der kan vinde deres Sag hos Folket...forestaa at tale til Hjærtet og sætte sædvanlig enhver borgerlig Sag i det rette lys. ${ }^{28}$ Fri konkurrence fra prædikestol og kateder - som i vore dages USA.

I Danskeren 1849 strammes synspunktet op, efter at Grundtvig har beklaget, at middelalderens frie, selvejer-bondestand blev undertrykt, og den samfundsmæssige rimelighed i gejstlighedens og adelens funktion forsvandt: 
"Disse nye, uægte Stænder er nemlig Embeds-Standen, Krigs-Standen, og Handels-Standen, hvortil i England og andetsteds, men dog, Gud skee Lov, ikke i Danmark, kommer Fabriks-Standen eller Maskineriet, der, saavidt mueligt vil afløse baade Bonden og Haandværkeren, ligesom Handels-Standen det hele Borgerskab, Krigs-Standen Adelen, og Embeds-Standen Geistligheden (og den udvikling må man bort fra)"

- - - Uden nemlig at tale om Fabrik-Standen, der bogstaveligt tager Brødet af Munden og aandelig piner Sjælen ud af Livet paa Folk, saa er baade Embeds-Standen, KrigsStanden og Handels-Standen i grunden slet ikke nærende men tærende og maatte tilsidst blive fortærende ... hverken i Folket eller for Folket, men kun paa Folkets Bekostning og til Dets Ødelæggelse." ${ }^{29}$

Denne opfattelse ligger helt på linie med Saint-Simons (og før ham med Quesnays) fremhævelse af uegentlige klasser vedrørende jurister og officerer, men er forskellig $\mathrm{i}$ ikke at tildele den industrielle entreprenør en aktiv og positiv rolle.

De gamle overklasser har udt $\varnothing \mathrm{mt}$ deres historiske rolle og de nye er parasitter og uden selvstændig værdi for samfundet. Alle i den udenlandske $\varnothing$ konomiske debat, Grundtvig direkte eller indirekte har kendt, har behandlet fremvæksten af den nye løse arbejderklasse i det industrielt-kapitalistiske system. Malthus, Ricardo og Say (den jernhårde lønningslov) havde hver på deres vis konstateret og beklaget de sociale omkostninger, men ikke ment at man kunne gøre noget ved de produktionsforhold, som frembragte den pauperiserede industriarbejder-klasse. Uddannelse, via samfundets indsats, børnebegrænsning via hævelse af moralen og andre industri-eksterne forslag så lyset fra den kant. SaintSimon på sin måde ved statens regulering og med øget kristelig næstekærlighed og Sismondi på sin måde mente, at der måtte gøres noget ved selve den industrielle produktionsform.

Men hvad mente Grundtvig herom. I Mands Minde talerne kombinerer han erfaringer fra England med hjemlige fabriksarbejderforhold i København samt antagelig overvejelser fra den engelske og franske debat. 
I det ofte citerede sted om det store, dampdrevne, fabriksanlæg på Gammelholm, virker dette skræmmende og

"...gjøre Mennesker i Tusindtal, baade store og smaa, til lutter Biting, lutter Appendixer til Maskineriet som Hovedsag og Grundkraft, saa selv de Engelskmænd, der giver sig Stunder til at tænke paa andet end at gjøre alt hvad de har i Penge, ser med hemmelig Gru paa enhver ny Opfindelse og kolossalsk Anvendelse af de mekaniske Grundkræffter, som efterhaanden fortrænge alle de gamle Haandværkere og gjøre dem til blotte Redskaber i Maskin-Mesterens Haand, tankeløse Trælle i Fabrikherrens Gaard."

På den ene side ville Grundtvig gerne udrydde teknologien, fabriksvæesenet og den kapitalistiske drift (den engelske Vindskibelighed), men på den anden side må han beundre fabriksvæesenet som et ekstremt stærkt udtryk "for levende Virksomhed" og trods alle fejl se det som et udtryk for åndens storværk. Han kan blot håbe på, at England vil indse sin fejltagelse:

"ved at ofre Mennesker i Hundredetusend-Tal til Maskineriet"..."og da vil den samme Kæmpe-Aand, som skaber Maskinerne, ogsaa forstaa enten at tilintetgjøre dem eller at sætte dem i et tjenligt og Tjenerligt Forhold til MenneskeVirksomhed og Menneske-Held. ${ }^{30}$

Andetsteds anfører han, at arbejderne netop ved den anførte proces, som appendikser til maskinen, mistede deres "lige værdighed" med andre borgere - altså nedværdigedes i den grad som mennesker - så de kun respekterede, "hvad der bider i Skind", dvs. prygl. ${ }^{31}$

Dette må være tilstrækkeligt til at vise, at Grundtvig var enig i Adam Smith' oven anførte fremstilling af arbejdernes fremadskridende fordummelse og fornedrelse som en naturlig følge af den industrielle proces.

Ovenfor er anført, hvorledes "Fabriks-Standen" i England afløste håndværkere og bønder. Men bemærkningerne ovenfor og flere andre steder om fabrikanternes "vindskibelighed", "aan- 
deløshed" osv. viser, at Grundtvig også fandt, at kapitalisterne var et negativt bidrag til en velfungerende samfundsorden.

Fabrikker som produktionsenheder, fabriksarbejdere og kapitalistiske fabrikanter var alle fra Grundtvigs synsvinkel uønskede bidrag til det danske økonomiske system.

I denne analyse er Grundtvig enig med Sismondi og en del konservative. Nogle konservative og nogle "utopister" forsøgte at fjerne problemerne med fabriksarbejderproletariatet ved at fjerne fabriksarbejdet - uden samtidig at anvise alternativ eksistensmulighed for den derved frigivne arbejdskraft.

\section{Bønder og håndvarkere som barende klasser via ejendomsrettens udbredelse}

Grundtvig så klart modsætningen og den klassemæssige spænding og udbytning ikke blot fra fabrikanten over for arbejderen, men også vedrørende "de nye klassers" udsugning af det arbejdende folk. Men modsat Marx og Engels så han ingen konstruktiv social dynamik i disse spændingsforhold. Spændingen skulle tvært imod ophæves ad to veje: dels ved at erkendelsen af det samlende skulle ske via selverkendelsen som folk, dels via satsning på bønder og håndværkere som samfundsbærende sociallag. Grundtvig erkendte industrialismens potentiale og økonomiske drivkraft, men fandt omkostningerne i menneskelig ulighed for høje og ville i stedet satse på et andet klassemønster end fx Englands.

Skønt det burde behandles for sig, slipper vi ikke her for at behandle ejendomsretten.

I ovenanførte økonomisk-politisk program fra juni 1848 fastslår Grundtvig ultimativt at:

"..Ejendomsretten er ikke blot det Borgerlige Selskabs Grundlov, men ogsaa dets Grundvold, saa naar den tages bort, synker hele Bygningen i Grus. ${ }^{32}$

Og denne sikring gentages længere nede i samme artikel - bl.a. fordi man ellers ikke kan få kapitalejere til at investere og "sætte Folk i Virksomhed". Senere i september 1849 fremhæver Grundtvig det heldige $i$, at der er mange og et stigende antal af selv- 
ejerbønder i Danmark. Over for det truende byproletariat er det nu:

"...aldeles nødvendigt, at de faste Eiendomme i et Land baade er fordelte mellem saa mange og saa haandfaste Selveiere, at de i paakommende Tilfælde kan forsvare Eiendomsretten, og at deres Stilling i det hele er saa god, at man $t ø r$ forudsætte, de ogsaa vil vove alt til dens Forsvar" (Adelen i Middelalderen havde en sådan rolle og Grundtvig ønsker at de nuværende godsejere er kloge nok til at virke for.) "...at Danmark fik et anderledes stort Tal stærke Selveiere, der var i stand til at forebygge eller, om det engang fandtes umueligt, tilgavns undertrykke et Oprør mod Eiendoms-Retten, som man i alle Riger herefter langt mere end hidtil vil staa (i) Fare for" (så mange som muligt skal have egen jord)..."men dog ikke udstykket saa småt, at selv en arbeidsom Mand slet ikke eller dog kun kummerligt kan leve deraf med Kone og Børn.." ${ }^{33}$

Det er jo klar tale i klassekamp-perspektiv - bønder mod storbyproletariat. Men samtidig er det $\emptyset$ konomi. Ejendomsret spredt til mange småproducenter - og dog skulle alle have så meget, at de kunne ernære deres familie deraf. Det blev Det radikale Venstres program 0. 1900. De store Landboreformer havde bevidst sat husmandslodderne så små, at husmanden for at ernære familien var nødt til at sælge sin arbejdskraft til bonden eller herremanden som daglejer. Grundtvig satsede på familiebruget - og dermed også på "Landeværnet", som bestod af et folk i våben, der havde noget at forsvare.

Grundtvig gør her som andetsteds opmærksom på, at helt fri ejendomsret har man kun til ting og menneskefrembragte værdier, men ikke til jorden som sådan. Til den har man en udvidet og sikret brugsret, men:

"ethvert Folk er sit Fædrenelands Grundeier (paa pluddervælsk "Suveræn") og kan aldrig retsmæssig ved nogen Lov tabe sin Eiendomsret"...(Det "fælles Bedste" for hele samfundet skal holdes for øje, og herremændene havde en afgiftsret, men deres ejendomsret var indskrænket)..."som en 
Nytte og Brug, der ikke maa forhindre, at Fattig-Folk jo ogsaa kan leve...Mennesket og Folket er hverken til for Statens eller for Agerdyrkningens, Kapitalernes eller for Handel-Balancens Skyld, men Jorden og alt Jordisk er til for Menneskenes og Folkets Skyld og skal benyttes til deres Bedste. ${ }^{.34}$

Denne opfattelse medfører, at Grundtvig ikke vil fri sammenlægningsret til jorden og gerne ser en slags livsfæste opretholdt bl.a. som sikring imod gård-opsplitninger.

Igen i det ovennævnte økonomiske program ser vi, at ejendomsretten (og næringsfriheden) skal være således indrettet, at den fremmer "den jævne Velstand og ønskelige Ligevægt". Skønt også håndværkerne nævnes $\mathrm{i}$ flere sammenhænge som "lige værdige" med gårdmændene, så er der ingen tvivl om, at tyngden i Grundtvigs planer, socialt og i praksis også økonomisk, ligger i at styrke mellemlaget af gårdmænd og gøre dem til den stabile kærne $\mathrm{i}$ et samfund, hvor klassernes "naturlige" spændinger afbalanceres.

Såvel den danske administrative og $\emptyset$ konomiske tradition som de ledende udenlandske $\emptyset$ konomer byggede på ejendomsrettens faste grundvold. Men vedrørende det grundlæggende element "jorden" ville Grundtvig ikke se den underlagt de frie markedsmekanismer $\mathrm{i}$ en liberal økonomi, således som det $\mathrm{fx}$ foregik $\mathrm{i}$ USA og var foregået i Frankrig efter revolutionstiden, med vilde jordspekulationer til følge - det var i øvrigt som jordspekulant, at Saint-Simon havde tjent den formue, der satte ham i stand til at udføre sit polit-økonomiske forfatterskab.

Men udover den hjemlige tradition, så ligger Grundtvigs klassepolitik og jordpolitik ud fra både sociale og økonomiske argumentationer så nær op ad Sismondis, at der må være en direkte påvirkning.

\section{Fattigdom, фkonomi og naestekaerlighed}

Fattigdomsproblemet er et af de områder, hvor Grundtvig direkte viser, at han har læst og sat sig ind i et socio- økonomisk områdes centrale litteratur. Sammen med industrialisering blev fattigdom 
som samfundsproblem uløseligt knyttet til lønarbejdets udbredelse og proletariseringen af arbejderklassen. I samfund uden større byer eller koncentrerede arbejdspladser (fabrikker) kan der ofte være - og har gennem historien været - en "skjult" arbejdsløshed på måske 20 - 30\% af arbejdsstyrken. Det var imidlertid familiens og slægtens sag at tage sig af de ubeskæftigede - dvs det var ikke et samfundsproblem. Flytningen af arbejdskraften fra rene landkredse til industribyerne i England fra sidst i 1700-tallet accentuerede problemet med, at industrialisterne væltede forsorgsproblemet for deres periodisk ubeskæftigede arbejdere over på agrarsektoren, hvor hjemsognene i England efter de gældende love fra 1600 skulle stå for fattighjælpen. ${ }^{35}$ Grundtvig er klar over denne problematik med den skjulte overførsel af ressourcer fra land til by via fattigkassen. Samvirken mellem to faktorer: den alment stigende befolkning samt den stigende arbejdsdeling synliggjorde fattigdomsproblemerne mere end tidligere samtidig med, at samfundene i ikke blot England, men i hele Nord- og Vesteuropa for første gang blev så velstående, at de kunne tænke på at gøre noget seriøst ved fattigdomsproblemet.

Med henvisning til Poor Law Report 1834 fremfører Grundtvig allerede i 1830 'erne, at fattigdomsproblemet ikke kan løses via fattighjælp fra de offentlige kasser. ${ }^{36}$ Senere i Mands Minde foredragene af 1838/39 vender han tilbage til de engelske erfaringer, hvorefter udgifterne til det engelske fattigvæsen fra 1811 til 1834 steg fra ca. 1 million $£$ årligt til ca. 11 mio. $£$, uden at det hjalp nævneværdigt på fattigdomsproblemet:

"..(I England) hvor hvert syvende Menneske er Tigger, og hvor da sikkert de fem syvendedele er fattige, dér maa den fattige endnu betale sit Brød dobbelt, for at Herremændene kan faa dobbelt Landgilde af deres Forpagtere ...(og) der var ingen Ret at naa for den fattige..."(bl.a. var det ikke lykkedes at få afviklet kornlovene) ${ }^{37}$.

Til gengæld levede den sidste syvendedel i overflod.

Kornlovene i England hæmmede udenlandsk korns adgang til det engelske marked og fordyrede dermed den fattiges daglige kost. De klassemæssige spændinger var i tiltagen, og man kunne 
befrygte en blodig revolution - fra neden. ${ }^{38}$ Det centrale var for Grundtvig, at det var ubærligt for staten "at skaffe alle Mennesker og Munde i Landet (England) Føden" Derfor kunne der ikke i den danske Grundlov stå noget om samfundets forsørgerpligt for andre end gamle, syge og forladte børn, de samme grupper, som i England var "værdigt trængende".

Men hvad ville Grundtvig da? Ville han som i Swifts satire lade de fattige mættes ved at spise deres egne børn? Nej, Grundtvig ville føre ansvaret for den fattige tilbage, hvor det efter hans mening hørte hjemme, til første cirkel i Fig. 5 ovenfor, "familien". Den anden mulighed for Grundtvig hørte vel hjemme primært i 2. cirkel af Fig. 5, dvs. i lokalsamfundet, hvor aktiv næstekærlighed skulle løse problemet. Som fungerende præst i en del år, hvor præsten var formand for sognets fattigkommission, kendte Grundtvig antagelig problemerne på nærmeste hold. I hvert fald tog han selv denne lokale næstekærlighed så alvorligt, at han - til andres forfærdelse og ikke særlig velovervejet - uddelte til de fattige af præstegårdens sædekorn i en alvorlig mangelsituation under hans virke som kapellan for faderen i Udby. ${ }^{39}$

I København virkede aktivt private godgørende selskaber med en vis succes. Det centrale var for Grundtvig at undgă, at samfundet og staten generelt påtog sig en forsørgerbyrde, som man alligevel ikke kunne magte. Det var mere væsentligt at koncentrere kræfterne om at sikre en samfundsstruktur af mellemlagsbønder og mindre næringsdrivende - et småborgerligt samfund - som ville hindre selve fremvæksten af et mere udbredt proletariat.

Set i historiens bakspejl havde Grundtvigs opfattelse meget for sig, idet netop den specifikke danske familiebrugsproduktion ${ }^{4 O}$ langt hen i 19. århundrede skabte og fordelte så meget arbejde $\mathrm{i}$ agrarsektoren, at de værste følger i form af overdødelighed m.v. af pauperiseringen blev undgået - $i$ modsætning til forholdene $i$ Irland, Sverige og Finland, hvor kriseår i agrarsektoren fulgtes af omfattende sultedød og store udvandringsbølger.

Danmark var økonomisk som samfund på Grundtvigs tid ikke så velhavende som England. Men i kraft af en anden klassestruktur og en anden økonomi havde Danmark mulighed for at undgå de værste følger af den økonomiske moderniseringsproces, også Danmark gennemgik. Disse muligheder havde Grundtvig øje for 
på trods af meget af samtidens officielle økonomiske visdom. ${ }^{41}$ Netop fordi det danske landbrug kunne opsuge meget arbejdskraft og støtte sig til en udbredt arbejdsdeling via landhåndværket uden for bysektoren, kunne den største del af det stigende antal i underklassen på landet holdes uden for fattigforsorgen - hvorved dennes basis $\mathrm{i}$ jordbeskatningen ikke brød sammen.

Grundtvigs analyse af klassesituationen og af fattigdomsproblemet var særdeles nøgtern og realistisk. Den sprogbrug og den offentlige argumentationsform, han anvendte, var dog så fjern fra eftertidens fors $\emptyset \mathrm{g}$ på "ren økonomi" - og fra samtidens akademiske formskærerlavs - at både samtid og eftertid synes at have overset, at han faktisk tænkte også фkonomi, men i sammenhaeng med en samfundsforståelse. Heri lå han på linie med alle de store fra sin samtid og umiddelbare fortid: Adam Smith, Th. Malthus, David Ricardo, Saint-Simon, Sismondi, osv.

Parallelt til, at staten ikke skulle blive en forsørgelsesanstalt for fattige, skulle den heller ikke efter Grundtvigs opfattelse blive det for embedsmændene gennem statslige pensioner:

"...man skal have saa faa Embedsmænd, som mueligt, og man skal lønne dem saa godt, som man kan, mens de giør deres Tjeneste; hvis de har tjent godt og længe, skal man give dem Naadsensbrød, men i øvrigt skal man lade Vorherre og dem selv sørge baade for deres Alderdom og for deres Koner og Børn." ${ }^{42}$

Sådan må bønder og borgere selv slide for mad og klæder, mens de har kræfter dertil, og så lægge til side til alderdom og familie. Jo mere de produktive skal afsætte gennem skat til embedsmændenes pensioner og familie, jo mindre bliver der til de virksomme borgere selv til at sikre dem og deres med. Det er for Grundtvig "Ligelighed" grundet paa sund fornuft og tidens krav.

Grundtvig var direkte, ja, næsten brutal i sin socio- $\varnothing$ konomiske og polit-økonomiske realisme "Kiendsgerningerne er nemlig, som Engelsk-manden meget rigtigt siger, haardnakkede Krabater. ${ }^{43}$ Samfundets borgerlige og økonomiske indretning måtte besluttes efter erkendelse af de barske realiteter: 
- klassekampen var en politisk og økonomisk realitet, men kunne drejes, så den ikke blev af engelsk karakter (efter Marx' analyse) med kapital og lønarbejde i uforsonlig konflikt;

- fattigdommen måtte bekæmpes ikke ved offentlig forsorg, men ved at hindre og hæmme udvikling af pauperiseringsfremkaldende produktionsformer (kapital og fabriksdrift) og i stedet bevidst satse på at styrke mellemlag og familiebedrifter i landbrug og håndværk - samt for en vis immateriel produktion, "munden".

Her skal blot bemærkes, at staten - som kirken - for Grundtvig var en samfundsmæssigt borgerlig institution, der var "til for Menneskenes Skyld, og Mennesket ikke til for Statens". Dette var i modstrid $\mathrm{fx}$ med Hegels statstænkning og megen praksis under enevældige og totalitære regimer.

Grundtvig mener, at en række samfundsområder hører under familiens eller lokalsamfundets ( $\mathrm{fx}$ menighedens) funktions- og beslutningsområde, hvorfor disse felter ikke skulle ind under Grundlovens myndighedsområde - og hertil hører bl.a. barneundervisningen og fattigfors $\varnothing$ rgelsen - bortset fra for dem, som er værgeløse og ingen ansvarlig har til at tage sig af dem. ${ }^{44}$

Men hvor blev næstekærligheden af som løser af fattigdomsproblemet og i det hele i økonomi-forståelsen? Det vender vi tilbage til.

\section{Liberalisme, frihandel og finanskapital}

Grundtvig var politisk længe tilhænger af "Kongehaand og Folkestemme", og altså tilbageholdende over for det konstitutionelle, repræsentative demokrati. Men i kulturelle og meningsdannende spørgsmål samt vedrørende фkonomien i cirkulationssfæren og i den primære (jordbrug) og den sekundære produktions-sektor (forarbejdede produkter, varer) var han liberal om en hals.

Konkurrencen $\mathrm{i}$ åbenhed - åndeligt og materielt - anså han for et grundvilkår for, at det bedste blev frembragt til borgernes nytte. Dette er tidligere så solidt påvist $\mathrm{i}$ forskningen, ${ }^{45}$ at jeg ikke skal 
optage pladsen med for mange eksempler eller for mange overvejelser.

I debatterne på Den grundlovgivende Rigsforsamling om Næringsfrihed 13.4.1848 ff. (spalte $2601 \mathrm{f}$ ) kommer dette naturligvis tydeligt frem. Men lad os se nærmere på emnet i Grundtvigs økonomiske programerklæring fra Danskeren 1848, del VI. Ejendommen skal sikres, men vedrørende finanskapitalen anføres, at den skal bruges til:

"at sætte Folk i Virksomhed og Næringsvej, da de ellers enten lægger Pengene paa Kistebunden eller seer at slippe bort, men Kapitalerne maae ingenlunde være saaledes frie, at de Rige dermed kan ødelægge hvad de kalder de Utrængte, som hverken er fattige eller rige, men har deres Udkomme, og kan og bør i hvert Land være de talrigste..."

Den likvide kapital skal investeres for at skabe beskæftigelse.

Men kapitalen må ikke uhindret køre på sine egne (profit og monopol) betingelser, der står ikke noget om af hensyn til lønarbejderne, men derimod klart, hvem det er, som skal beskyttes imod kapitalens regimente.

Det er de "utrængte", dvs. de, som kan og vil forsørge dem selv og deres, - og det tydeliggøres ved, at disse "utrængte" skal være den talrigeste gruppe i landet. Det er altså igen et klart klasse-synspunkt i en polit- $\emptyset$ konomisk forståelsesramme, der er fremlagt.

Grundtvig forsætter sit program:

"Nærings Veiene maae altsaa i høi Grad giøres og holdes frie, saa de hverken bindes ved Laugstvang, BevillingsKlemme og Toldforbud, eller bebyrdes med Nærings-Skat og Fattig-Skat, eller undergraves af store Fabrikker.."

Den første del frem til "Næringsskat" er helt klart et opgør med feudalsamfundets og den kameralistiske stats grænsesætninger. Både produktion og omsætning (handel) skulle have frie virkeforhold. Det er liberal økonomisk erhvervspolitik samtidig med, at indskrænkninger i told og skattegrundlaget nødvendigvis 
måtte reducere statens magt og mulighed for at gribe regulerende ind.

Så vidt, så godt for den almindelige næringsdrivende - men hvad med kapitalens og maskinteknologiens indbyggede monopoliseringstendenser? Her ses det klart, at hverken kapital eller produktionsorganiseret teknologi i fabrikssystemet skal tillades altså ingen dominans for organiseret kapital eller organiseret maskinelproduktion på de små næringsdrivendes bekostning.

Den stærke holdning imod enhver form for monopoler kommer frem mange steder i forfatterskabet, og er ganske veldokumenteret. I 1850 skriver han med baggrund i så lille en sag, som om Thorvaldsens Museum skal have monopol på afstøbninger af kunstnerens værker, om de af:

"...alle Frihedens, Lighedens og Driftighedens Venner forhadte Monopoler," (og fortsætter om andre tilsvarende, fx universitetets monopol på almanakker, der er til).."Skade for Næringen og for Folket i det hele, som maa kiøbe daarligt og dyrt, hvad de, uden Monopolerne, vilde faae godt og billigt.." ${ }^{n 6}$

Vender vi tilbage til det økonomiske program, så stoppede vi faktisk midt i en sætningskæde, der hos Grundtvig fortsætter:

"...men man maa slet ikke lægge an paa at sikre de $\mathrm{Næ}$ ringsdrivende deres Ophold, da man derved kun føder Dovenskab og alt Ondt, forgriber sig paa Eiendommen og standser den fri Omsætning, der ligesom Blodets fri Omløb i vort Legeme, er Vilkaaret for det Borgerlige Selskabs sunde Tilstand.."

Inddrager vi iagttagelserne for forrige afsnit, så ses det, at det ikke er statens sag at understøtte

- fattige, der kan arbejde med fattigforsorg,

- embedsmaend, med pensioner,

- naeringsdrivende, ved at sikre deres ophold. 
Når man ikke er ramt af sygdom eller alderdom osv., så er det $\mathrm{i}$ $\emptyset v r i g t$ enhvers pligt at sørge for sig selv og sine. I det punkt er Grundtvig altså lighedsmand. Alle skal stå lige uden beskyttelse over for livets farer. Den enkelte skal ikke blot være politisk fri, men også økonomisk fri, med de farer og den ansvarlighed dette medfører.

Ved på den ene side at fjerne det statsligt økonomiske sikkerhedsnet og på den anden side beskytte den enkelte middelstandsborger mod monopoler og angreb fra organiseret kapital og organiseret fabriksmaskineri blev frihed og ansvar reelt både politisk og фkonomisk for et samfund, hvor de fleste var mindre næringsdrivende eller leverede kvalificeret arbejde med "Haand" eller "Mund".

Pengene, den mest mobile del af den flydende kapital, var for Grundtvig ikke i sig selv vaerdiskabende, og det var ej heller maskineriet eller jorden. Kun arbejdet - delt i åndeligt og fysisk arbejde - var værdiskabende for samfundet. Den potentielle arbejdsomhed og virkelyst skulle gives de frieste betingelser for under ligelig konkurrence at skabe både kvantitativt og kvalitativt optimale goder til befolkningens flertal. Handelen og finanskapitalen var $\mathrm{i}$ denne proces nødvendige som blodstrømmen $\mathrm{i}$ legemet, men skabte ikke i sig selv reelle værdier - jf., at handelsstanden oven for egentlig var at opfatte som en parasitgruppe på linie med advokater og officerer.

Om man vil kalde Grundtvigs økonomi-forståelse for småborgerlig, reaktionær, liberal, konservativ, evolutionær, fysiokratisk - eller hvad, vil jeg overlade til andre at skændes om.

Derimod vil jeg kalde den realistisk og dansk. Det første, fordi den nøgternt tog de faktiske produktionmæssige, historiske og klassemæssige forudsætninger ind $i$ en socio- $\varnothing$ konomisk og polit$\emptyset$ konomisk helhedstænkning. Det andet, fordi Grundtvig af de mange tilbud på de økonomiske teoriers marked tog af dem - og transformerede dem - som gav mening og kunne anvise handlingsmuligheder i Danmark uden at hævde andet, end at de måtte vise deres værdi i den danske praksis. 
Afslutning - фkonomiens drivkroefter:

egenkarlighed, det falles bedste og lige vardighed

Et $\emptyset$ konomisk system - dvs. den bevidste og ubevidste koordinerede samvirken mellem mennesker for at frembringe, fordele og konsumere materielle og immaterielle goder - har i sig dels tendenser mod balance, dels en dynamik mod forandring og/eller ekspansion. Balancen igen kan afløses af perioder med turbolens og uro (ustruktureret forandring) og så søge mod en ny balance. Dynamikken kan afløses af stagnation (negativ forandring), ekspansionen kan være kontinuær eller foregå i spring og kan veksle imellem sådanne tilstande.

Den klassiske økonomi søgte at finde en begrænset og overskuelig mængde af variabler, der kunne sættes i meningsfulde og forudberegnelige relationer til hverandre. Dette var selvfølgelig en abstraktion $\mathrm{i}$ forhold til en kompleks virkelighed med principielt uendelig mange variabler. Denne abstraktionens problem var naturligvis alle de store $\varnothing$ konomiske teoretikere sig bevidste om det drejede sig om at finde de voesentligste faktorer og sætte dem i meningsfuld sammenhæng. Det klassiske eksempel er Malthus' opstilling af fødevareproduktionens mulige lineære vækst og befolkningsudviklingens tendentielle eksponentielle vækst. Grundtvig kunne ikke fordrage den "døde" matematik og tendensen til, at naturvidenskaben - og økonomien - i stigende grad blev matematicifieret. På den anden side bøjede han sig for resultaterne af ægteskabet mellem matematik og naturvidenskab i teknologiens maskineri.

Overfor "rationelle" økonomiske tænkere stod folk med opfattelser mere på linie med et organisme-vaekstbegreb, som bl.a. prægede en del af den romantiske filosofi og forskning. Forholdet mellem Grundtvig og den romantiske tænkning er diskuteret mange steder $\mathrm{i}$ forskningen, - det vil jeg lade ligge og blot konstatere, at Grundtvig var påvirket af romantisk tankegang, samtidig med at han bevarede træk af oplysningstidens holdninger osv. - men prægede det hans фkonomiske tænkning? Organismetænkningen indeholdt jo reelt et vaekst-og forandringsbegreb.

Men hvad drev værket, hvad var "kraften" i økonomi-tænkningen. Hos Adam Smith var det arbejdet kvalificeret ved arbejdsdel- 
ingen og retningsorienteret ud fra egennytten, som holdt det $\emptyset$ konomiske maskineri i gang. Som ført af en "usynlig hånd" viste det sig for erfaringen, at summen af de samvirkende egeninteresser faktisk førte til det foelles bedste, selvom ingen bevidst havde søgt dette.

Profitmotivet og kapitalens indbyggede trang til akkumulation samt det funktionsopdelte arbejdes n $\varnothing$ dvendighed for eksistensen hang for Marx sammen med den tiltagende sociale spænding mellem rige og fattige (kapitalister of proletarer) og drev $\phi k o n o m i e n$ fremad, til den gennem revolutionen sprængte de politiske rammer og skabte nye samfundsformer.

For Malthus var befolkningsvæksten af naturens orden, dvs. kønsdriften var en grundfaktor i økonomien ved siden af arbejdet. Arbejdet skabte mad, klæder, husly, osv. Moralen måtte for Malthus tøjle kønsdriften, i praksis ved afholdenhed fremmet ved sen ægteskabsalder.

Hvad var for Grundtvig drivkraften ud over håndens og åndens arbejde? I opgøret med de parisiske værksteders idé 1848 hævder Grundtvig, at økonomisk egennytte (egoisme) ikke kan gå som drivkraft, men netop bliver til ulykke, når den synliggøres og almengøres, og samtidig hævder han, at ens løn til alle uanset faktisk arbejdsindsats også må føre til alles ulykke. Omvendt kan egenkærligheden som kollektivt fænomen i folkeligheden være en aktiv og legitim styrke i folkelivet. I familien - vedrørende forsorg for egne nødstedte - ser vi menneskekærligheden som en central faktor. På det folkelige plan mangfoldiggøres det positive fra familiekærligheden op på det kollektive plan, men dette gælder helt tydeligt ikke for Grundtvig uden videre på det økonomiske plan.

For det enkelte arbejdende menneske er kærligheden set med Grundtvigs øjne en stærk drivkraft netop til konstruktivt arbejde, omsorg i kærlighed for sine nærmeste og ikke af pligt. Derfor må dét grundlæggende produktionsmønster fremmes som sikrer den enkelte størst mulighed for gennem arbejdet - fysisk og åndeligt - at omsætte kærligheden til praktisk økonomisk sikring af sig og sine.

I de helt nære relationer er kærligheden aktiv og konstruktiv dvs. livskabende. Egen-kærligheden er en side af kærligheden og er ikke nødvendigvis skadelig. Det afhænger af dens udfoldelses- 
betingelser, der kan blive positive i den folkelige sfære. Men den folkelige dimension af livet fungerer kun, hvor folk er - ikke ens men "lige værdige". I den rent $\emptyset$ konomiske sfære derimod er faren for den enes udnyttelse af den anden eller af de mange, bl.a. gennem monopoler, konstant nærliggende. Klassekampen er for Grundtvig en destruktiv realitet, der nødvendigvis vil komme, hvor fordeling og produktion virker i samme retning til at forøge de manges afhængighed af de få. Det industrielle klassesamfunds proletarer havde for Grundtvig ingen menneskelig ære og værdighed - de var tabt for et folkeligt fællesskab, der netop må samles om at forsvare, opretholde og udbygge de fælles kulturelle og materielle værdier. Den folke-ånd eller nordiske kæmpe-ånd, hvis løsen var bedrifter, - dvs. legemliggjort $\mathrm{i}$ handlinger og frembringelser, $\mathrm{fx}$ i damphammerens jættekraft - var et historisk (tidsdimensionalt) og samfundsmæssigt fænomen fra virkelighedens verden, som blandt andet fremgik af den måde, hvorpå økonomien fremtrådte i dagliglivet.

Folkeånden var altså det krydsfelt, hvori kærligheden konstruktivt kunne vekselvirke med andre skabende kræfter, der omsattes til social praksis bl.a. i økonomien på en måde, som på den ene side muliggjorde evolution i stedet for revolution $i$ et samfund af lige værdige medlemmer, men på den anden side krævede en bevidst indsats for at denne mere afbalancerede udvikling kunne lykkes over for de også mulige og mere destruktive tendenser.

Grundtvig forsøger bl.a. i sin økonomisk-politiske tænkning at løse det balanceproblem mellem den individuelle "vice" (egennytten) og den almengjorte "virtue" (det fælles bedste), som havde plaget økonomi- og samfundstænkningen fra Mandeville (The Grumbling Hive, 1705) til Adam Smith, og som den sidste havde søgt at komme uden om ved at hævde, at gennem markedets medierende og fordelende potentiale transformeredes $\mathrm{i}$ varen den individuelle egennytte til det fælles bedste ${ }^{47}$. Både kærlighed $\mathrm{i}$ Grundtvigs brede forstand og hans opfattelse af folkelighed (kvalitativt) og folkeånd indeholder $\mathrm{i}$ sig afspejlinger af det guddommelige. For Grundtvig var det guddommelige til stede i det menneskelige, og måske er det her koblingen sker for ham til at løse Mandevilles paradoks om, hvorledes egennytte kan transformeres til almen-nytte. Den "lige værdighed" i menneske- 
livet kobles hertil, men betyder for Grundtvig ikke demokratisme eller udviskning af sociale og naturskabte forskelle - tvært imod det betyder, at enhver inden for samfundets komplekse helhed har sin værdi og sin ret til at blive respekteret for sin indsats. Måske er der i denne tanke om "Lige Værdighed i Borg og Hytte" (1820, Langt højere Bjerge...) en parallel til en opfattelse af lige værdighed over for det guddommelige. En nøjere gennemgang af Grundtvigs prædikener og salmer vil antagelig kunne bidrage til afklaring heraf. I hvert fald viser Grundtvig selv udad og tilbage i sit forfatterskab ved at slutte sit økonomiske program fra 1848 af med at vise tilbage til sin sang fra 1820 om det gode samfund, "hvor Faa har for meget og Færre for lidt---".

Politikken og kulturen hang hos Grundtvig uløseligt sammen med og vekselvirkede med $\emptyset$ konomien i det borgerlige samfund og heri er han uden at have tiltænkt det enig med Marx. Men hertil må aldrig glemmes, at menneskelivet og folkelivet $\mathrm{i}$ den historiske virkelighed i borgersamfundet, hvori det udfoldede sig, altid for Grundtvig ogs̊ vekselvirkede med og antog sin dybeste menneskelige form og fandt sit fulde udtryk i kristenlivet.

Det ene var ikke uden det andet. 
Tekst til Grundtvigs фkonomiske program

(Hovedpunkterne i Grundtvigs økonomiske opfattelser fremstillede han i foråret 1848 for offentligheden i sit tidsskrift Danskeren i en artikel-serie 29/3-28/6 i syv dele under fællestitel, "Den danske,den tyske og den franske Sag", hvor især del VI er vigtig. Jf. Haandbog,II, s 177-78 samt Begtrup, Udv. Skrifter, s. 236-39; henvisninger her til sidetal hos Begtrup):

Eiendoms-Retten er ikke blot det Borgerlige Selskabs Grundlov, men ogsaa dets Grundvold, saa naar den tages bort, synker hele Bygningen i Grus.

Modsætningen af de faa Rige og de mange Fattige er, om end ikke allevegne lige stor og skiærende, saa dag allevegne stor nok til i vore selvraadige Dage at sætte Eiendoms-Retten i Livsfare, da det for den overfladelige Betragtning er en smal Sag at raade Bod paa den oprørende Ulighed, ved at tage fra de Rige og give til de Fattige; men kan vi ellers blive klog af Andres Skade, da er det en stor Lykke for os, at vi frem for alt i Paris, som alles Øine vogte paa, kan klarlig see, at de saakaldte National-Værksteder, som vil sikkre alle Arbeidere, baade gode og slette, god Fortjeneste, er paa Veie til at undergrave alt hvad de ei opsluge, uden dog selv at kunne bestaae! Sagen er nemlig den, at var alle Mennesker, baade de Fattige og de Rige, Dydsmønstre, da var det ingen Sag at skifte og dele broderlig imellem dem, men da behøvedes det ikke, thi da havde alt, uden Love og Borgerligt Selskab, jævnet sig selv. Nu derimod, da vi er alle Syndere, maa det naturligviis blive splittergalt, naar vi alle behandles som Dydsmønstre, og det af Folk, der selv er Syndere og tit nogle af de Groveste, saa enhver Øvrighed, der vil træde i Forsynets Sted og lære Vorherre, hvordan Han skulde skiftet Lod og Lykke, saa det gik ligeligt til, den maa nødvendig ikke blot beskæmme sig selv og begaae himmelraabende Uretfærdighed, men, standses den ikke snart i Farten, giøre alle baade Rige og Fattige grændseløs ulykkelige.

Enhver klog og menneskekiærlig Øvrighed vil der for lade den Steen ligge, som ingen Haand kan løfte, og kun alvorlig stræbe, ved den størst muelige Nærings-Frihed og Eiendoms-Sikkerhed, at fremme den jævne Velstand og ønskelige Ligevægt, mens den, 
saavidt mueligt, ved velgiørende Indretninger sørger for de Børn og Gamle, Syge og Vanføre, som findes hjelpeløse i deres nærmeste Kreds.

Eiendommen maa nemlig være i høj Grad sikker, naar de Fleste, som har noget, dermed skal stræbe at sætte Folk i Virksomhed og Næringsvei, da de ellers enten lægge Pengene paa Kistebunden eller seer til at slippe bort, men Kapitalerne maae ingenlunde være saaledes frie, at de Rige dermed kan ødelægge hvad vi kalder de Utrængte, som hverken er fattige eller rige, men har deres Udkomme, og kan og bør i ethvert Land være de talrigste.

Nærings-Veiene maae altsaa i høi Grad giøres og holdes frie, saa de hverken bindes ved Laugstvang, Bevillings-Klemme og Toldforbud, eller bebyrdes med Nærings-Skat og Fattig-Skat, eller undergraves af store Fabriker, men man maa slet ikke lægge an paa at sikkre de Næringsdrivende deres Ophold, da man derved kun føder Dovenskab og alt Ondt, forgriber sig paa Eiendommen og standser den fri Omsætning, der, ligesom Blodets fri Omløb i vort Legene, er Vilkaaret for det Borgerlige Selskabs sunde Tilstand. - - -

Alle Baand paa Nærings-Veiene lade sig neppe løse; men det giælder her som altid derom, at de, der staaer for Styret, styre den rette Kaas og ei den modsatte, saa enhver er saa sikker som mueligt paa hvad han virkelig besidder, og enhver kan saa frit, som mueligt, søge sin Næring, hvor han troer at finde den. - - -

I Danmark, hvor Selveiernes Antal er godt i Tiltagende, og hvor de store Fabriker Gud skee Lov! er faa, vil det ikke falde vanskeligt at redde Selvhaves Liv, afskaffe al anden Fors $\emptyset$ rgelsesRet end den indbyrdes mellem Forældre og Børn, og at indføre saa stor en Nærings-Frihed, at det kan gaae, som der staaer i Visen:

Faa har for meget og Færre for lidt. - -48 


\section{Noter}

1 Haandbog, II, 128-29.

2 Et sjældent eksempel er henvisningen til "Report on the Poor Laws", der må henvise til Nassau Senior, m.fl.: "Report of the Royal Commission of the Poor Laws", 1834. (Haandbog, I, s. 31) jf. uddrag derfra i Rose, Poor Law, s. 75-134).

3 Hovedpunkterne vedr. merkantilisme, fysiokraterne, kameralisme efter artikler derom i Handwörterbuch der Sozialwissenschaften, 1-12, 1956f. samt E. Roll, Economic Thought endvidere Boserup, Deres egne ord, endelig Harrison, British Political Thought, samt læsning af en række af de originale arbejder fra oplysningstiden og de tidlige borgerlige samfund, jvf. litteraturlisten.

4 Hørstbøll, "Folkebøger", i Wåhlin, Historien i kulturhistorien, s. 294, f.

5 Bloch Ravn, Thomas, "Fortiden i nutiden, om moralsk økonomi" i Wåhlin, Historien $i$ kulturhistorien.

6 Jf. H.C. Johansen, Dansk фkonomiske politik, s. 15, om hvorledes blot 2 danske forfattere havde sat sig ind i ikke mindre end 39 kendte økonomiske forfatterskaber, de fleste fra England, Frankrig og Tyskland og nogle få fra andre lande. Jf. også hos H.C.J. om samspillet mellem teori og økonomisk politik i Danmark sidst i 1700-tallet. Leisner, Den oplyste Enevaelde, giver en kort og solid karakteristik af en række af de stats- og samfundsteorier, som med europæisk baggrund kom til at indgå i den danske, oplyste enevældes idégrundlag (og dermed også i Grundtvigs baggrund); Leisner supplerer fortræffeligt L. Kaaes grundlæggende udredning af angel-saxiske samfundsteoretikeres betydning for Grundtvig, i "Ikkun som voxne Menneske-Børn". 
7 Mogens Boserup, Deres egne ord s. 67 vedr. Adam Smith, bringer i uddrag de centrale økonomiske pointer hos fysiokrater, liberalister, osv.

8 Francois Quesnay et la Physiocratie, I-II. Paris 1958. Gengivelse efter Boserup, Deres egne ord, 1976.

9 Adam Smith. Wealth of Nations, book V, chap. I, part IV, art.2.

10 Boserup, s. 72.

11 Utilitaristerne efter Harrison, British Political Thought. chap. 910-11 om Paine, Bentham og James Mill. s. 123-172.

12 Owen, Report to the County of Lanark, s. 269-74.

13 Mill, Principles, Book II, chap. II, \$6 og Book IV, chap. VII, $\$ 6$ og $\$ 7$.

14 Ricardo, Works and Correspondence, vol. IX, s. 243 f. Jf Boserup, Deres egne ord s. 127 om Sismondis notat om samme møde.

15 Jean-Charles-Léonard Sismonde de Sismondi, Nouveaux Principes de l'Économie politique, 1827. Sismondis store og kendte historiske værker om Frankrigs og Italiens historie må Grundtvig have kendt. Sismondis økonomiske arbejder falder senere $\mathrm{i}$ forfatterskabet og bygger på omfattende rejser og studier. Grundtvig må direkte eller indirekte have kendt Sismondi - der er for mange paralleller. Jf. også Roll, Economic Thought, s. $235 \mathrm{f}$.

16 Se fx C.N. Davids udførligt diskuterende anmeldelse i Maanedskrift for Litteratur., II, 1829 af C. Dirckinck-Holmfeld, "Englands und Amerikas neuere Handelspolitik", 1828. David opridser her liberalismen som et program - men tilpasset dansk virkelighed og med advarsel mod økonomisk dogmatisme. Se endvidere de mange artikler i Statsøkonomisk Archiv, $1826 \mathrm{f}$. redigeret af C.N. David. 
17 De centrale tekststeder fra de 3 hovedarbejder Le système indutriel (1821-23), Catéchisme des industriels (1823-24) og Le nouveau Christianisme (1825) findes i Saint-Simon, Textes choisis, Paris, 1951.

18 "les industrielles", dvs de virksomme (både arbejdere og arbejdsledere ses over for en anden kategori - "industrialistes" i.e. iværksættere og arbejdsgivere). På dansk findes en udmærket, kort indføring i Saint-Simon og den samtidige polit$\emptyset$ konomiske debat i Leisner, Europas historie, s. 115 - 129.

19 Jf. Roll, Economic Thought om de tyske tænkere, s. 211 - 231.

20

Efter Boserup, Deres egne ord, s. 137. Boserup fremhæver rigtigt, at oplysningstidens filosoffer foretog den første udskillelse af økonomien som en særlig gren af samfundstænkningen (så man overhovedet kunne tale fornuftigt om økonomi, bl.a. ved at skabe økonomiske modeller). Alligevel vil jeg mod Boserup hævde, at det først var i 2. halvdel af det 19. århundrede, at adskillelsen fra den $\emptyset$ vrige samfundstænkning reelt fandt sted og slog igennem.

21 Danskeren 1849, s. 564 jf. også Baagø, Grundtvig og engelsk liberalisme, s.8.

Wåhlin, Ikke stykkevis og delt, s. 21 - 23.

23. Kampen mellem modsætningerne som livets vilkår fra "Fortalen til Nordens Mythologi"; af Danskeren 1.6.1849 afsnit om den sønderjyske krig, "Liv er i Kamp".

24 Tidende for ...Grundlovgivende Forsamling sp 2601. 13. april 1849. jf. sp 3203, jf Haandbog, II, s. 291.

Haandbog II, s. 96-97.

Ibid., s. 100. 
${ }^{27}$ Første citat fra N.F.S. Grundtvig, Vaerker $i$ Udvalg, $V$ s. 281. 2. og 3. citat fra Danskeren, $V I$ afsnit af "Den danske, den tyske og den franske Sag" 29.3 til 28.6.1848, Haandbog, II, s. 177-78.

I Mands Minde talerne, på Rigsdagen med flere steder kan lignende udsagn findes.

${ }^{28}$ Haandbog, II, s. 96-98.

29 Ibid., s. 215-16 fra "Danskeren", artikelserie "Overgangs-Tiden i Danmark" 3.2. til 10.3.1849.

30 Mands Minde foredrag. 14. november 1838.

31 Wåhlin, Ikke stykkevis og delt, s. 41. I de større byer i udlandet ..."findes en stor Vrimmel, som man paa pluddervælsk kalder "Proletarier", som sædvanligvis hverken har Eiendom, visse Værelser, Hjerte elle Ære i Livet, og kan kun holdes i Ave ved Frygt for hvad der bider i Skind." Haandbog, II, s. 221.

32 Haandbog, II, s. 177.

33 Rent faktisk bakkede landets største godsejere op om et sådant program fra $1851 \mathrm{i}$ "Grundejerforeningen" ved hvis virke 10.000 af tønder land blev købt fra fæste til selveje til rimelige priser. Wåhlin, "Politiseringsprocessen" i Danmark 1830 - 1870, del III, manus 1980.

34 Haandbog, II, s. 273. Tale 13.3.1849, 1. behandling af Grundlovsudkastet.

35 Sidney and Beatrice Webb, English Local Government, I, 1963. samt Rose, Poor Law passim.

36 Haandbog, I, s. 31.

37 Mands Minde, 183827.6 i Haandbog II, s. 81.

38 Grundlovudvalgets behandling, § 70, 14.4.1849, Ibid., s. 292. 
De ca. 50.000 - 60.000 familiegårdbrug fra 1 - 12 tønder hartkorn i dyrkningsværdi (ca. 10 - 120 td land i flademål eller ca 12 - 140 acres), udgjorde ca. $75 \%$ af den dyrkede jord i 19. århundrede, Wåhlin, "By og land", s. 31.

Det skal anføres, at også C.N. David og andre danske økonomer i samtiden, fx. Nathanson, selvom liberale, reelt ikke lå langt fra Grundtvig, skønt deres sprogbrug var ganske anderledes. Et interessant indblik heri findes hos Clemmensen, $D e$ religiøse Systemers Indflydelse paa de erhvervsetiske Principper..., 1940.

42

Danskeren 8.6.1850, m.fl.st. også, bl.a. i Rigsdagen, Haandbog, II, s. 231.

Tale, 14.3.1848, Ibid., s. 158.

44 13.3.1849 på Grundlovgivende Rigdagsforsamling, sp. 1886 m.fl. st. Ibid., s. 272.

45

De vigtigste her er: Baagø, Grundtvig og den engelske liberalisme (1949) og Lars Kaae, "Ikkun som voxne Menneske-Børn" i Stykkevis og delt, 1986.

46 Danske Rigsdags-Breve, III "Danskeren" 1850, s. 198 - 99. Haandbog, II, s. 292.

47 Jvf. herom det tankevækkende afsnit (kap. 6) "Politik, økonomi og moral" i Østerud, Det moderne statssystem, s. 87-106.

48 Danskeren 1848, 29/5 - 28/6. En artikelrække i 7 Stykker, "Den danske, den tyske og den franske Sag," Del IV. Jvf. Haandbog, II, 177-78 og Begtrup, Udv. Skrifter, s. 236-239. 


\section{Litteraturliste}

Andersen, Poul: Grundtvig som Rigsdagmand og andre Afhandlinger. 1940.

Bang, J.P.: Grundtvig og England. 1932.

Bekker-Nielsen, Tønnes (red.): Stykkevis og delt - 5 essays om Grundtvig og grundtvigianisme. Århus. 1986.

Bentham, Jeremy: Economic Writings, vol. I f. (ed. W. Stark). London. $1952 \mathrm{f}$.

Boserup, Mogens: Deres egne ord. En antologi over den фkonomiske videnskabs historie. 2.udg. Kbh. 1976.

Baag $\varnothing$, Kaj: "Grundtvig og den engelske liberalisme". Grundtvig Studier. 1955. s. 7 - 37.

Clausen, Sven: De danske statsteorier. Kbh. 1953.

Clemmesen, Wolmer: De religiøse Systemers Indflydelse paa de erhvervsetiske Princippers Udvikling i Danmark fra Reformationen indtil det 19. Aarhundrede. 1940.

Dam, Poul: Politikeren Grundtvig. Århus. 1983.

David, C.N.: Anmeldelse af Constant Dirckinck-Holmfeld. "Englands und Amerikas neuere Handelspolitik". Maanedsskrift for Litteratur, II. 1829. s. 126 ff.

Fabricius, Jørgen: N.F.S. Grundtvigs breve til hans hustru under Englandsrejsen 1843. Grundtvig Studier. 1952. s. $39 \mathrm{ff}$.

Grundtvig, N.F.S.: Grundtvigs Breve til hans hustru under Englandsrejserne 1829-1831. Udgivet af hans Børnebørn. Kbh. 1920.

Grundtvig, N.F.S: Christelige Praedikener eller Søndags Bog, I - II. $1827 \mathrm{f}$.

Grundtvig, N.F.S: Udvalgte Varker, 1 - 9. (udg. P.A. Rosenberg) Kbh. u.a.

Handwörterbuch der Sozialwissenschaften, 1 - 12. 1956 f.

Harrison, Wilfred: Sources in British Political Thought 1593 - 1900. N.Y.-Lond. 1965.

Horstbøll. Henrik: "Folkebøger, folkelig læsning og folkekultur i Danmark 17. - 19. århundrede," i V. Wåhlin. Historien $i$ kulturhistorien. 1988. s. 294 - 316.

Haandbog $i$ N.F.S. Grundtvigs Skrifter. Udg. E.J. Borup og Frederik Schrøder, I - III. Kbh. 1930. 
Iversen, Hans Ravn: And og livsform. Husliv, folkeliv og kirkeliv hos Grundtvig og sidenhen. Århus. 1987. Anm. af W. Michelsen, Grundtvig Studier. 1987. s. 57 - 62.

Johansen, Hans Chr.: Dansk фkonomisk politik i årene efter 1784, I. Århus. 1968.

Jørgensen, Aage: Grundtvig litteratur 1963 - 1985. En bibliografi. Århus. 1986.

Kaae, Lars: "Ikkun som voxne Menneske-Børn: Grundtvig og frihed" i Bekker-Nielsen (red): Stykkevis og delt. Århus. 1986. s. $75-122$.

Leisner, Johnny: Europas historie i det 19. århundrede. Kbh. 1967. Lotz, Johann Friedrick Eusebius: Handbuch der Staatswirtschaftslehre. 1821 - 22. (2. udg. 1837 - 38).

Malthus, T. R.: Essay on Population. 1. ed. 1798 (fl. udg.).

Manuel, Frank E.: The Prophet of Paris. (1962) 1965 (om SaintSimon).

Mill, James: Elements of Political Economy. (1821) 3.ed. London. 1826.

Mill, John Stuart: Principles of Political Economy. London. 1848. (fl.udg).

Møller, Erik: Grundtvig som Samfundskritiker. 1950.

Maanedsskrift for Litteratur. Kbh. 1829 f.

Owen, Robert: "Report to the County of Lanark" (1829) i A New View of Society and other Writings. London. 1927.

Proudhon, Pierre Joseph: Qu'est-ce que la propriété ou recherches sur le principe du droit et du gouvernement. Paris. 1840.

Quesnay: François Quesnay et la Physiocratie, I-II. (ed. I.N.E.D.). Paris. 1958.

Quesnay, François: Maximes générales du gouvernement économique d'un royaume agricole, Paris. 1767.

Ravn, Thomas Bloch: "Fortiden i nutiden - mental inerti og moralsk økonomi i Danmark fra middelalderen til idag" i V. Wåhlin. (red) Historien i kulturhistorien. 1988. s. 235 254.

Ricardo, David: Works and Correspondence (ed. Sraffa) vol I XI. Cambridge. 1951 ff.(Heri de klassiske afhandlinger: Principles of Political Economy and Taxation. (1817) m.fl.). 
Roll, Eric: A History of Economic Thought 2. ed. London. 1962.

Rose, Michael E.: The English Poor Law 1780 - 1930. Newton Abbot. 1971.

Saint-Simon, Claude-Henri de: Textes choisis. Paris. 1951.(Heri centrale uddrag af: Le système industriel (1821 - 23); Le nouveau Christianisme (1825) og Catéchisme des industriels, 1823 - 24).

Say, Jean Baptiste: Traité d'Économie politique. Paris. 1803.

Senior, Nassau W.: An Outline of the Science of Political Economy. London. 1836.

Sismondi, Jean Charles Léonard Sismonde de: La Richesse commerciale. Paris 1803.

Sismondi, Jean Charles Léonard Sismonde de: Nouveaux Principes de l'Économie politique. Paris. (1819) 2. udg. 1827.

Statsøkonomisk Archiv (red) C.N. David. 1826 f.

Thaning, Kaj: F.N.S. Grundtvig. (Eng. ed.) Kbh. 1972.

Thaning, Kaj: "Grundtvig og den grundlovgivende rigsforsamling" i Grundtvig Studier. 1949. s. 35 - 73.

Thodberg, Christian og Anders Pontoppidan Thyssen: N.F.S. Grundtvig Tradition and Renewal. 1983. (parallel dansk udg.)

Thompson, William: An Inquiry into the Principles of the Distribution of Wealth most Conductive to Human Happiness. London. 1824.

Thompson, William: Labour Rewarded. London. 1827.

Todberg, Helge: "N.F.S. Grundtvig: "Indfald"', i Grundtvig Studier. s. 7 - 15. 1949.

Webb, Sidney og Beatrice: English Local Government. English Poor Law History, Part I. The Old Poor Law. (reprint) London. 1963.

Wåhlin, Vagn: Politiseringsprocessen i Danmark I - III. (manus) Århus. 1979.

Wåhlin, Vagn: "By og land. Omkring dynamikken i forholdet mellem socio- $\varnothing$ konomisk basis, klasser og ideologi i Danmark i det 19. århundrede - forsøg til en syntese." i J. Holmgaard (red): Det grundtvigske bondemiljø. 1980a. s. 1 - 73 . 
Wåhlin, Vagn: "Bourgeois and Popular Movements in Denmark" i Scandinavian Journal of History. vol. 5. 1980b. s. 161 183.

Wåhlin, Vagn: "Tiden 1700 - 1870". (En diskussion om Hans Chr. Johansen, En samfundsorganisation i opbrud 1700 - 1870. i Dansk Socialhistorie bd. 4. 1979) Den Jyske Historiker nr. 23 - 24. 1982. s. 77 - 113.

Wåhlin, Vagn: "Ikke stykkevis og delt", i T. Bekker-Nielsen (red) Stykkevis og delt. Århus. 1986. s. 9 - 52.

Wåhlin, Vagn: "Opposition og statsmagt. Legale rammer og myndighedernes reaktionsmønstre over for de frembrydende borgerlige politik-former under den sene enevælde." i Fl. Mikkelsen (red) Protest og oprør. $1986 \mathrm{~b}$.

Wåhlin, Vagn: "Popular Revivalism in Denmark - Recent Research Trends and Results", i Scandinavian Journal of History. vol. 11 (4). 1987. s. 363 - 387.

Wåhlin, Vagn.(red): Historien i kulturhistorien. Århus. 1988a.

Wåhlin, Vagn: "Fra statshistorie til kulturhistorie", i V. Wåhlin (red) Historien i kulturhistorien. Århus. 1988b.s 55-88.

Østergård, Uffe. "Bønder og danskere - et essay om dansk men talitet og politisk kultur" i V. Wåhlin (red) Historien $i$ kulturhistorien. Århus. 1988b. s. 317 - 371.

Østerud, Øyvind: Det moderne statssystem og andre politiskhistoriske studier. Oslo. 1988. 